\title{
Leasing Human Capital: Toward a New Foundation for Employment Termination Law
}

\author{
Daniel J. Libenson $\dagger$
}

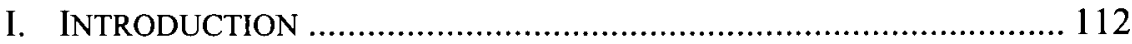

II. THE RISE AND DECLINE OF EMPLOYMENT AT WILL ..................... 116

A. The Emergence and Consolidation of the Employment-at-

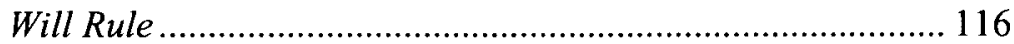

B. The Defense of the Employment-at-Will Rule ......................... 117

C. The Opposition to Employment at Will................................... 122

D. The Dilution of Employment at Will ..................................... 127

E. Reform of Employment Termination Law.............................. 130

1. META 's Provisions ................................................. 132

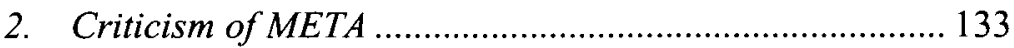

F. A New Hope: Employment at Will with Mandatory

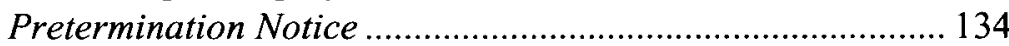

III. FROM SALE OF LABOR TO LEASE OF HUMAN CAPITAL ................... 136

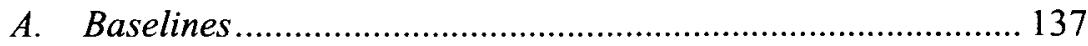

B. Human Capital in Labor Economics .................................... 139

C. Employment as a Lease of Human Capital............................. 140

D. The Law of Bailments ........................................................... 143

E. The Duty of Ordinary Care as Applied to Employment

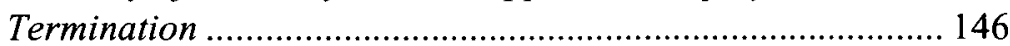

1. Job Loss Causes Devaluation of Human Capital ............ 147

2. Costs to Employers of a Good Cause Rule ...................... 150

$\dagger$ Assistant Professor of Law, University of St. Thomas School of Law. J.D., Harvard Law School. The author wishes to thank Richard Primus, Scott Taylor, Teresa Collett, Rob Vischer, Noah Feldman, Beth Niestat, Norman Williams, Jeffrey Standen, Vincent Chiappetta, Gregory Sisk, Thomas Berg, Mitchell Gordon, Rene Bowser, Michael O'Connor, Celia Rumann, Michael Dorff, Eliot Fishman, Morton Horwitz, Kathy Graham, Henry Hammer, Karin Roffman, and Samuel Libenson, all of whom contributed to the development of the ideas in this Article or provided important support and guidance at critical junctures. The author is also grateful to Kate Nilan, Adam Brown, Paul Beckman, and Daryl Atkinson for outstanding research assistance. 
3. Balancing Employee and Employer Interests:

Mandatory Pretermination Notice.

a. Advance Notice and the Preservation of Human

Capital.

b. Advance Notice and Employer Flexibility. 155

F. Mandatory Pretermination Notice as a Solution to the Employment Termination Law Problem 156

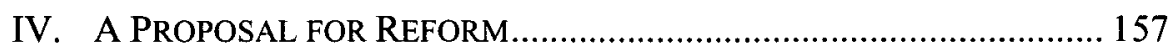

A. The Basic Rights and Duties.................................................. 158

B. Exceptions to the Notice Requirement .................................. 159

1. Malfeasance and Gross Incompetence.............................. 160

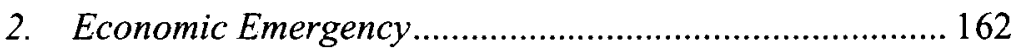

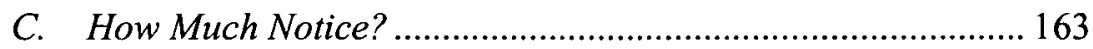

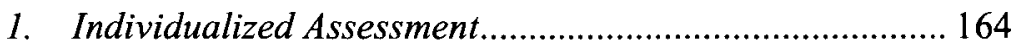

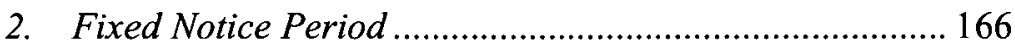

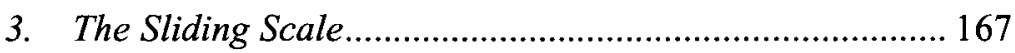

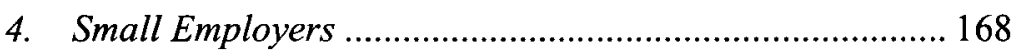

5. Room for Experimentation ................................................ 170

D. Consequences of Unjustified Failure to Give Notice .............. 170

E. Statutory and Common Law Exceptions to Employment at Will in an Ordinary Care World........................................... 172

F. Contracting Around the Duty of Ordinary Care ..................... 173

G. A Tale of Two Approaches: Comparison with the Model Employment Termination Act ............................................ 174

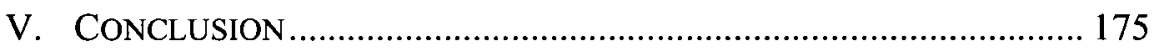

I.

\section{INTRODUCTION}

American employment termination law is a mess, and neither employees nor employers get what they need from it. The law in every state but Montana is based on the employment-at-will rule, which gives employers the unrestricted right to fire employees who do not have definiteterm employment contracts, ${ }^{1}$ but courts and legislatures have also created numerous exceptions to the rule, the application of which can be extremely unpredictable. As a result, employees live in perpetual fear that their livelihoods can be pulled away from them at their employers' whims, causing them to feel stifled and uneasy at work, unable to be themselves,

1. See, e.g., Payne v. Western \& Atlantic R.R. Co., 81 Tenn. 507, 519-20 †1884) ("All may dismiss their employees at will, be they many or few, for good cause, for no cause or even for cause morally wrong, without being thereby guilty of a legal wrong."). 
and even-as recent business scandals make clear-afraid to speak up about the unethical or unlawful behavior of others. The situation for employers is an unhappy one as well. The fear of being sued by a former employee based on one of the growing number of exceptions to the at-will rule causes employers to engage in a variety of expensive and inefficient self-protective activities, including intrusive pre-hire background checks, continuous documentation of even minor employee misconduct, and failing to fire poor performers. This Article proposes a new approach to employment termination law that would make both employers and employees better off.

Efforts to solve the problem of U.S. employment termination law have faltered, I believe, because the debate has become trapped by the assumption that there are only two alternatives to the classic employmentat-will rule, which places no restrictions on the right to fire. The first alternative is to retain the at-will rule subject to specific limitationsemployers may fire employees for any reason unless the reason is one that our society deems especially bad. ${ }^{2}$ This exception-riddled at-will rule is what governs American employment termination today. American employers may fire employees for no reason at all, and they may fire employees for any reason that is not specifically prohibited by state or federal statute or by judicial interpretation of common law tort and contract principles. The second alternative, which most opponents of the current system propose, is to get rid of the at-will rule entirely and allow employers to fire employees only for "good cause" or "just cause." While the scope of permissible firings under such a system is debated at the margins, supporters of a move to good cause generally mean that only serious employee misconduct or incompetence on the one hand, or serious employer economic difficulties on the other, could justify a termination.

Because the absolutist form of the at-will rule is no longer a serious possibility, two camps have formed. In one camp are those who believe that the at-will rule is sound but are willing to consider-sometimes quite grudgingly-some modest limitations. In the other camp are those who believe that the at-will rule must be replaced by good cause. When a debate becomes polarized in this way, it can be resolved only by power, by compromise, or by the emergence of a hitherto unnoticed third way.

Neither side in the debate appears to have the power to get its way. Indeed, the steady creep of exceptions to the at-will rule satisfies no one; atwill supporters lament the unnecessary dilution of a sound rule, and at-will opponents view the exceptions as distractions from the real problem, which is that no employee should have her livelihood subjected to the whim of her employer. The main attempt at compromise-the Uniform Law

2. See Paul C. Weiler, Governing the WORKPLACE 51 (1990), for explication of this view. 
Commissioners' Model Employment Termination Act ("META")-has not been adopted by even a single state. Either META is a poor compromise that satisfies no one and has thus failed to generate the political support needed for passage, or no compromise is likely to generate such support because compromises are inherently uninspiring. At the end of the day, we are left with a de facto compromise that no one wants. We have retained a basic commitment to the employment-at-will rule, but we have riddled it with many more exceptions than at-will's supporters deem acceptable without giving the level of protection that at-will's opponents believe is the moral minimum.

This Article proposes a third approach to resolving the problem of employment termination law. My proposal is based on a principled reconceptualization of the basic nature of the employment relationship and on an attempt to find a solution that addresses the most serious concerns of both employers and employees. My proposal is not a compromise, in which no one wins and no one loses, but a third way in which everyone wins most of what they need and loses only a little.

The new foundation for employment law that I propose here is based on conceptualizing the employment relationship as a lease of human capital from employee to employer. A lessor generally owes a duty of ordinary care to the lessee-that is, the lessee must treat the lessor's property as if it were her own. If employment is like a lease, this would mean that employers ought to be required to care for the value of employees' human capital-that is, their lifetime income-generating potential-as if that human capital were the employers' own. I suggest that in the context of the termination of employment, the best way to protect the value of employee human capital is to give sufficient pretermination notice to allow the employee to find a comparable new job before losing the old one.

Most Americans probably understand-at least at some deep intuitive level-that many employees are treated unfairly by employers and suffer terribly both from the fear of being fired and from actually being fired. Americans also understand that employers must sometimes fire employees based on business needs that do not always rise to the level of justification that would prevail in court against a de facto standard of life tenure. Thus, to choose between the two polar opposites-the employment-at-will rule and the good cause rule-is to be forced to choose an approach that neither solves the problem nor does justice. The question is whether a sound rule can be fashioned that does feel like justice.

In the pages that follow, I will argue that it is possible to find a third way that accords with our intuitive sense of workplace justice and that achieves a fair and workable balancing of the most important needs of employers and employees. To be sure, my solution raises difficulties and disappointments for both, but on balance I believe that it leaves employers 
and employees better off than they are under the current system. Furthermore, because my proposal is based on principle rather than compromise, accords with most Americans' intuitive sense of workplace faimess, does not represent total victory for one side over the other, and makes both employers and employees better off than they are under the current system, it has a much better chance of being adopted in some form than META or any other compromise proposal does.

In Part II of this Article, I give an overview of the history of the employment-at-will rule and an intellectual history of the debate over its merits. I describe the emergence of the employment-at-will rule in the nineteenth century and the increasing number of exceptions to it that emerged throughout the twentieth century. I also examine the scholarly debate over whether and how to limit an employer's right to fire his employees. Two major fault lines determine what side people are on in this debate. The first fault line relates to whether the scholar focuses on the needs of the employer or of the employee. The second fault line relates to whether the scholar is focused on fairness or economic efficiency. I conclude by introducing META, the model act that was designed as a compromise.

In Part III, I lay out a reconceptualization of the employment relationship, asserting that it is more similar to an equipment lease-the equipment being the employee's human capital - than to a purchase and sale of labor outputs. Leases form bailment relationships in which the lessee takes on a duty of ordinary care over the leased property in his possession; the law requires the lessee to care for the lessor's property as if it were his own. If employment is more analogous to a lease than to a purchase and sale, perhaps employment law could benefit from looking to the law of leases. This Part concludes that requiring employers to exercise ordinary care over their employees' human capital would mean that employers must try to avoid damaging the value of that human capital when they terminate their employment. The best way to do this, I suggest, is to require employers to give pretermination notice to employees, which would allow employees to attempt to secure a comparable new position before they are faced with the desperation of looking for work while unemployed and with the stigma of having been labeled as someone who was fired.

In Part IV, I discuss the challenges of translating the duty of ordinary care and the requirement of pretermination notice into a new legal regime to govern employment termination. My aim in this section is not to make a comprehensive proposal for a new statute or model act. Rather, my goal is to highlight the types of questions that would need to be addressed by such a statute (or statutes, as I think state experimentation is likely the best way to figure out what works). 
Finally, in Part V, I conclude by briefly discussing why both employers and employees should be interested in adopting a third-way solution to the problem of employment termination law.

II.

THE RISE AND DECLINE OF EMPLOYMENT AT WILL

The history of the employment-at-will rule in America and the academic arguments over its appropriateness have both been much debated and often recounted in scholarly writing about employment termination law. The purpose of this overview is to show how discomfort with the rule has led to its scaling back by courts and legislatures as well as much criticism by academics over the course of the twentieth century. At the end of the day, however, neither courts nor legislatures, nor academics, nor the Uniform Law Commissioners have been able to replace the at-will rule with a workable alternative that responds to its weaknesses and preserves its strengths.

\section{A. The Emergence and Consolidation of the Employment-at-Will Rule}

Perhaps the knowledge that employment at will was not always the law in the United States can free our collective imagination to consider whether there might not be something better. It comes as a surprise to many to learn that the Angio-American system did not always allow the unrestricted termination of employment. Indeed, the at-will rule only consolidated its hold in the United States in the late nineteenth century. In England, beginning at least with the Statute of Artificers in 1563 and persisting through the nineteenth century, employment contracts were presumed to be for one year. ${ }^{3}$

Scholars dispute whether the one-year presumption was ever the rule in the American colonies. ${ }^{4}$ Eventually, the presumption was replaced by the

3. See Sanford M. Jacoby, The Duration of Indefinite Employment Contracts in the United States and England: An Historical Analysis, 5 COMP. LAB. L.J. 85, 90 (1982). Blackstone explained that the one year presumption was based on "a principal of natural equity" that the servant, supported through the winter by the master, must not leave just before the growing season, and the master must not fire the hard-working servant at the end of the harvest when he will be unlikely to find a new position. See id. (quoting William Blackstone, CommentaRIES, Chicago, 1872, 425); see also Deborah A. Ballam, The Traditional View on the Origins of the Employment-at-Will Doctrine: Myth or Reality?, 33 AM. BuS. L.J. 1, 2 (1995). But Sanford M. Jacoby has written persuasively that the rule was in fact calculated, along with other rules, to ease the pain that labor shortages would have caused employers and that too many terminations would have caused local parishes and towns that were required by poor laws to support impoverished ex-servants. See Jacoby, supra, at 86-89.

4. Compare Jacoby, supra note 3, at 91 (the one year presumption was the rule in the colonies), with Deborah A. Ballam, The Development of the Employment-at-will rule Revisited: $A$ Challenge to its Origins as Based in the Development of Advanced Capitalism, 13 HOFSTRA LAB. \& EMP. L.J. 75, 98 (1995) ("[E]mployment at will appears to have been the standard practice for all categories of labor [in New York] from colonial times through the nineteenth century.") 
employment-at-will rule, which held that employers were free to fire their employees without the need to justify their actions. Some scholars claim that employment at will was always the presumption in America, ${ }^{5}$ while others say that it took hold only in the late nineteenth century. ${ }^{6}$ Scholars agree that Horace Wood's 1877 treatise was influential in the consolidation of the at-will rule in America. Wood wrote: "[W]ith us, the rule is inflexible, that a general or indefinite hiring is prima facie a hiring at will, and if a servant seeks to make it out a yearly hiring, the burden is on him to establish it by proof." " As Andrew P. Morriss writes, "At some point early in [the twentieth century], the at-will rule became the generally accepted default rule in the United States. A lengthy period of relative quiet ensued."

The employment-at-will rule, with its image of the employee and employer engaging in an arm's length purchase and sale of labor, certainly fit well with the laissez-faire spirit of the late nineteenth and early twentieth centuries. ${ }^{9}$ Indeed, the rule accorded so well with the values of late nineteenth century and early twentieth century America that the Supreme Court briefly constitutionalized it during the Lochner era, deeming any restriction on the right to fire a violation of the employer's liberty and property rights. ${ }^{10}$ New Deal cases such as NLRB v. Jones \& Laughlin Steel Corp. ${ }^{11}$ overturned these holdings and made it possible for unions to form and negotiate good cause protection for their members. Non-unionized employees remained subject to unregulated termination.

\section{B. The Defense of the Employment-at-Will Rule}

Legal scholars have offered a number of justifications for the employment-at-will rule, defending it on both fairness and economic efficiency grounds. These defenders view the employment relationship as a basic everyday economic transaction. In their view, not only is the employment relationship an economic transaction, but it is a particular kind

5. See, e.g., Ballam, supra note 4 , at 98 .

6. See, e.g., Jay M. Feinman, The Development of the Employment-at-will rule, $20 \mathrm{AM}$. J. LEGAL HIST. 118,126 (1976).

7. See Horace G. Wood, a Treatise on the Law of Master and Servant Covering the RELATION, Duties, AND LiABILITIES OF EMPLOYERS AND EMPloYeES (Albany, N.Y., John D. Parsons, Jr. 1877).

8. Andrew P. Morriss, Exploding Myths: An Empirical and Economic Reassessment of the Rise of Employment At-Will, 59 Mo. L. REV. 679, 688 (1994).

9. See Kenneth A. Sprang, Beware the Toothless Tiger: A Critique of the Model Employment Termination Act, 43 AM. U. L. REV. 849, at 861-62 (citations omitted). (1915).

10. See Adair v. United States, 208 U.S. 161, 174-75 (1908); Coppage v. Kansas, 236 U.S. 1, 17

11. 301 U.S. 1 (1937). 
of economic transaction, namely a purchase by the employer of marginal units of labor output supplied by seller employees.

Defenders of the at-will rule have little interest in the human dimension of the employment relationship or the capacity of its termination to harm the human dignity of employees. While their economic perspectivewhich has come under increasing fire in recent years-is generally rigorous and thoughtful, their defenses of the at-will rule strike many as cold and one-sided because they fail to balance the economic arguments against the human suffering that results from unjustified terminations.

Richard Epstein, the leading intellectual defender of the employmentat-will rule, devotes only a few paragraphs of his aptly titled In Defense of the Contract at Will ${ }^{12}$ to the question of the rule's fairness ${ }^{13}$ because the answer seems utterly obvious to him. Epstein sees the employment relationship as merely one of a number of "day-to-day business transactions"14 that an individual transacts, and he believes that it should therefore be treated by the law just like any other transaction. Epstein sees no compelling reason to depart from the usual rules of contract that he believes would apply to any other analogous transaction: "So long as it is accepted that the employer is the full owner of his capital and the employee is the full owner of his labor, the two are free to exchange on whatever terms and conditions they see fit .... If the arrangement turns out to be disastrous to one side, that is his problem; and once cautioned, he probably will not make the same mistake a second time." 15 The real-world persuasive power of Epstein's argument is undercut by his obvious failure to consider the human drama of job loss.

Taking Epstein's argument on its own terms, although he does not explicitly say so, it is clear that when he writes of the employment relationship as an "exchange," Epstein means that it is a purchase and sale of labor, that the employee exchanges a daily contribution of labor units for a daily wage. Other proponents articulate the labor-as-commodity perspective with even greater directness. Gail Heriot, for example, writes that "the employee trades labor for wages; the employee allows an employer to control his or her activities during working hours in return for

12. Richard A. Epstein, In Defense of the Contract at Will, 51 U. CHI. L. REV. 947 (1984).

13. See id. at $953-56$.

14. Id. at 954.

15. Id. at 955 . It should be noted that not everyone agrees that the at-will presumption is an appropriate one even if employment is thought of as a typical contract for exchange. Jay M. Feinman, for example, writes that contract law at the time that the at-will rule took hold, "was designed to give effect to the manifest joint intention of the parties regardless of the nature of the transaction." Feinman, supra note 6, at 130 . Thus, a more appropriate regime would be one that looked to various sources of evidence as to the employer's intent and the employee's intent, not one that established a heavy "artificial presumption of terminability." Id. 
cold, hard cash." ${ }^{\prime 16}$ In her view, this makes the employer-employee relationship "indistinguishable from any other market transaction-an exchange of goods or services freely entered into by the parties and nothing else." ${ }^{17}$ As I will explain later, however, even Heriot's description of the relationship actually accords better with viewing it as a lease.

In addition to freedom of contract, the rule's defenders assert that any restriction on the right to fire constitutes an unjustified abridgment of the employer's property and association rights. Because the employer owns the workplace, he should have the right to control who is in it; ${ }^{18}$ and the law should not force a person to continue to associate with another person if he no longer wants to do so. Richard Power, along these lines, emphasizes the personal dimension of the employment relationship and the impossibility of forcing people to continue to work together if one of them no longer wants to. ${ }^{19}$ Comparing employment to marriage ${ }^{20}$ Power asserts that when one party to a personal relationship no longer wants the relationship, the relationship "can no longer function effectively."21 The employment-at-will rule is justified, like no fault divorce, by the lack of a realistic alternative. ${ }^{22}$ Power also thinks that the employment-at-will rule may be good for employees in that it forces them to find the jobs for which they are the best fit-not only on paper but in terms of personality and other intangibles. ${ }^{23}$

The employment-at-will rule also draws praise for its simplicity. It is easy for employers and employees to understand $\mathrm{d}^{24}$ and for the courts to implement. If employers need not justify terminations, then courts need not determine whether the employee is actually guilty of the incompetence ascribed to him, a determination that could require sorting through and analyzing a great deal of disputed factual evidence and a great deal of a court's time. ${ }^{25}$ Also, if we fear that juries--made up mostly of employees - will be biased in favor of employee-plaintiffs, the employment-at-will rule allows cases to be kept away from juries

16. Gail L. Heriot, The New Feudalism: The Unintended Destination of Contemporary Trends in Employment Law, 28 GA. L. REV. 167, 168 (1993).

17. Id. at 168 .

18. See Jack M. Beermann \& Joseph William Singer, Baseline Questions in Legal Reasoning: The Example of Property in Jobs, 23 GA. L. REV. 911, 946 (1989).

19. Richard W. Power, A Defense of the Employment at Will rule, 27 ST. LouIS U. L.J. 881, 888 (1983).

20. See id. at 889-90.

21. Id. at 888 . Power compares this justification for the at-will rule to that for no-fault divorce. See id. at 889 .

22. See id.

23. See id. at 892.

24. See Epstein, supra note 12 , at 955 .

25. See Power, supra note 19 , at 886. 
altogether ${ }^{26}$ Granted, there is a cost to employees fired without cause, but if one believes that unfair termination is not widespread, the cost savings in judicial administration may outweigh the cost to employees (as a class) of the at-will rule. ${ }^{27}$

The employment-at-will rule has famously been defended by neoclassical law and economics scholars, most notably Richard Epstein, as the most economically efficient rule-certainly more efficient than good cause - to govern the employment relationship. The fundamental argument is that the threat of being fired serves to drive employees to work as hard as they can. Because an employee receives less in wages than the profit his firm receives from his work, Epstein posits that the employee will not work as hard as the employer would want him to without some prodding. ${ }^{28}$ Thus, argues Epstein, there is a mismatch between the level of effort that the employer wants and the level of effort that the employee would naturally give. $^{29}$ The employer can only get more effort from the employee by using "carrots" (such as higher wages or promotions) ${ }^{30}$ and "sticks." ${ }^{31}$ The easiest and cheapest sticks for the employer to use are those that "can be unilaterally exercised: to fire, to demote, to withhold wages, or to reprimand. ${ }^{\prime 32}$ Thus, employers prefer an at-will regime in which they retain the power to use these sticks. Even though arbitrary or malevolent firings are possible under an at-will regime, Epstein is confident-although he submits no data to back up a confidence that would probably strike the vast majority of Americans with real-world working experience as naive in the extreme-that imprudent firings will be kept to a minimum by employers' fears that good employees will quit preemptively if they come to believe that they might be the next to go even though they are performing well. ${ }^{33}$ Epstein also believes that the fact that employers will have to "find, select, and train a replacement worker who may not turn out to be better than the

26. This is one of the major reasons that Andrew Morriss thinks nineteenth century courts adopted the at-will rule in the first place. See Morriss, supra note 8, at 752-53.

27. See Power, supra note 19 , at 896.

28. See Epstein, supra note 12, at 963 .

29. See id. at 964 .

30. See id. Obviously, however, the greater the percentage of the profit received by the employee the less the firm is able to succeed in its purpose of making a profit.

31. See id. at $964-65$.

32. Id. at 965 .

33. See id. at 968 . Epstein's confidence in the deterrence value of reputational concerns may be unwarranted, even in the case of the hypothetical "rational actor" employer. Lawrence Blades pointed out long ago that employers may not need to be especially concerned about their reputations in difficult economic times, in which current and prospective employees have few other options. See Lawrence Blades, Employment at Will vs. Individual Freedom: On Limiting the Abusive Exercise of Employer Power, 67 COLUM. L. REV. 1404, 1413 (1967). Employers can claim that a terminated employee was fired for cause and "silence" the few employees who may know that the firing was without good cause by using their own fear of being fired for spreading the word. See id. at 1413 . 
first employee"34 will also serve to prevent employers from firing employees who do not deserve it.

Epstein also asserts that at-will employment is better for most employees because the rule makes it easy for employers to get rid of poor performers who force the good workers to pick up their slack ${ }^{35}$ and because employers are more likely to take hiring risks since they know that they need not be stuck with a bad worker forever. ${ }^{36}$ Finally, employment at will is best because it is "very cheap to administer." would open the door to much litigation and would introduce expensive error costs due to sympathetic juries and problems with proof. ${ }^{38}$ Because, Epstein believes, it is rare for an "innocent employee" to be "wronged by a firm vendetta," 39 and because he thinks that good employees who are wrongly fired can find new work without much trouble-another questionable proposition that also fails to take seriously the enormous costs to individuals who are not able to find a new job-the costs of a change outweigh the benefits. ${ }^{40}$ Epstein takes comfort in the freedom of employers and employees to change the terms of employment through contract. ${ }^{41}$ Other scholars have extended and built on Epstein's work, ${ }^{42}$ but Epstein remains the at-will rule's iconic defender.

While the correctness of Epstein's various assertions and premises have been called into serious question, ${ }^{43}$ what is clear is that Epstein does

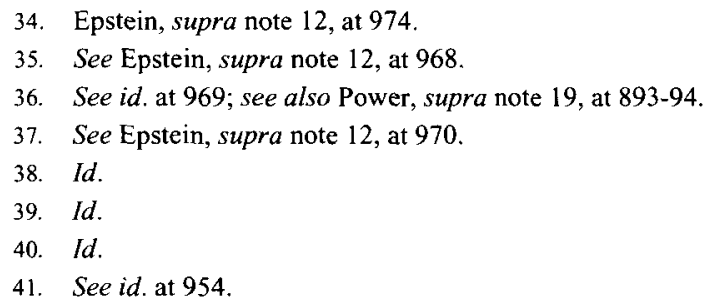

42. See, e.g., Meyer G. Freed \& Daniel D. Polsby, Just Cause for Termination Rules and Economic Efficiency, 38 EMORY L.J. 1097 (1989); Andrew P. Morriss, Bad Data, Bad Economics, and Bad Policy: Time to Fire Wrongful Discharge Law, 74 TEX. L. REV. 1901, 1905-15 (1996). Although Epstein's economic defense supports an unadulterated at-will rule, scholars who accept his economic paradigm appear to accept civil-rights-based limitations on the right to fire and even support a few other exceptions to the employment-at-will rule when they believe that there are systematic reasons for pervasive market failure. See, e.g., Stewart J. Schwab, Life-Cycle Justice: Accommodating Just Cause and Employment at Will, 92 MiCH. L. REV. 8 (1993).

43. Opponents have long argued, for example, that a severe bargaining power imbalance prevents employees from successfully obtaining good cause protection through contract; this argument is supported by the fact that when bargaining power is more equal--in the unionized workplaceemployees obtain good cause protection. See WEILER, supra note 2, at 50. Another strong argument of longstanding asserts that employees are afraid to negotiate termination provisions before they are hired because they do not want to signal to the employer that they are in any way contemplating being fired. See Samuel Issacharoff, Contracting for Employment: The Limited Return of the Common Law, 74 TEX. L. REV. 1783, 1795 (1996). In addition, the empirical work of scholars in the growing field of behavioral law and economics is raising a new set of questions. Most notably, Pauline Kim has challenged Epstein's claim that there is no "reason to believe that [at-will] contracts are marred by misapprehensions," Epstein, supra note 12, at 955, a premise that underlies both Epstein's fairness and 
not regard the employment relationship as anything more or less than a typical economic transaction between two individuals even though the consequences of an unjust termination of the relationship can be devastating to the employee. Thus, maximizing the economic efficiency of the transaction ought to be the driving force behind the shaping of the law that governs it.

In sum, Epstein and other defenders of employment at will focus on the nature of employment as a market transaction between the employer and the employee, a trade of labor for wages. Because permitting either party to terminate such an exchange relationship at will accords with the way we treat other similar transactions and because, they say, license to terminate the relationship at will is also the most economically efficient choice, the law should not restrict an employer's right to fire an employee except in rare cases of pervasive market failure.

\section{The Opposition to Employment at Will}

The employment-at-will rule has proven quite unpopular in the pages of American law journals. Most opponents of the rule focus on the costs to wrongly-fired employees, whether those costs are economic, dignitary, or psychological. Because they view the costs to the individual as unacceptably high, opponents generally agree that employees should be given some form of property right in their jobs, a right protected by an

efficiency arguments. See Pauline Kim, Bargaining with Imperfect Information: A Study of Worker Perceptions of Legal Protection in an At-Will World, 83 CORNELL L. REV. 105, 106 (1997). Kim conducted surveys of unemployed individuals and found that their understanding of the employment-atwill rule is inaccurate. See id. Most employees--even employees who have recently lost jobs-appear to believe that the law gives them something akin to good cause protection. See id. at 133-47. Indeed, about three quarters of the survey respondents believed that it was unlawful to fire an employee in order to hire another at a lower salary even if the employer's personnel handbook stated that the employer "reserves the right to discharge employees at any time, for any reason, with or without cause." Id. at 139. Economists believe that if an informed subset of the consumer population-"comparison shoppers"-is large enough, these comparison shoppers will be able to achieve competitive prices for all; but, according to Kim, the proportion of potential employees who are informed consumers, who understand the employment at will background rule, is too small to constitute even an effective comparison shopper group. See id. at 147-50. Schwartz and Wilde believed that one-third of the population in question was a sufficient comparison shopper group, but Kim found that fewer than $10 \%$ of those who completed her survey got more than $50 \%$ of the questions right. Id. at 150 (citing Alan Schwartz \& Louis L. Wilde, Intervening in Markets on the Basis of Imperfect Information: A Legal Analysis, 127 U. PA. L. REV. 630, 651-53 (1979)). Kim's work demonstrates that the most likely reason for the fact that employees do not contract around the employment-at-will rule is that they do not know about it. Kim, supra, at 150-51. Kim argues that Epstein is mistaken in his claim that if employees really wanted good cause protection, they would bargain for it because they would not bargain for something they think they already have. See Kim, supra, at 153. Much more empirical study is needed to determine whether the various claims of Epstein and the other efficiency-based defenders of employment at will are correct. How sensitive are employers to reputational concerns? Do they take steps to "cover up" the true reasons an employee was fired? In the meantime, Kim's work suggests that the theory is likely not as ironclad as its proponents claim. 
employer's obligation to show "good cause" or "just cause"-that is, serious employee misconduct or incompetence or employer economic difficulty-to take that job away. Such a property right would reduce unfair termination to the absolute minimum, but it would also, of course, make it very difficult and expensive to fire people when such firings are justified. The weakness of the advocates of a good cause system is their failure to consider seriously enough the concerns of employers about a system in which all or most employees have a right to keep their jobs indefinitely.

The most prominent early attacks on the at-will rule came from Lawrence Blades, ${ }^{44}$ in 1967 , and Clyde Summers, ${ }^{45}$ in 1976. A steady stream of criticism has flowed from the legal academy ever since. The precise nature of the criticism varies, but an important common denominator is that the at-will rule essentially gives employers an unchecked right to impose devastating economic and personal harms on undeserving individuals. Although some opponents have challenged the economic efficiency arguments of Epstein and the other defenders, questioning their premises and conclusions, most either ignore the efficiency arguments altogether or appear to argue that the potential costs to individual fired employees - or to society as a whole-are intolerable and outweigh the general efficiency gains under an at-will system.

Blades focuses on the at-will rule's threat to individual freedom. Because for employees "the substance of life is in [the employer's] hands," $" 46$ employers can use the threat of termination to force employees to act in ways that they do not want to. ${ }^{47}$ The fear of being fired, Blades writes, forces many employees to violate their own moral codes, if not the law, on a regular basis. ${ }^{48}$ In a society in which most citizens are employees, the modern employer may be as much a threat to individual freedom as is the government. ${ }^{49}$ Just as government power is checked in the United

44. See Blades, supra note 33.

45. See Clyde W. Summers, Individual Protection against Unjust Dismissal: Time for a Statute, 62 VA. L. REV. 481 (1976).

46. Blades, supra note 33, at 1404 (quoting Frank TANNenbaum, A Philosophy of Labor 9 (1951)).

47. See id. at 1405.

48. See id. at 1407-08. Recent scandals in the business world at companies like Enron and WorldCom, and the fact that so few employees appear to have spoken out against their employers' fraudulent practices in those cases, can be taken as anecdotal evidence that such concerns are well founded. See Dan Ackman, Whistle-Blowers Need Incentives, FORBES.COM, July 18, 2002, http://www.forbes.com/home/2002/07/18/0718whistle.html.

49. See id. at 1407 . Blades was especially concerned that the fear of being fired might force employees to commit unlawful acts or forego important rights. See id. at 1407-08. Some of these concerns are reduced in states that have adopted the tort of wrongful discharge against public policy, which is discussed briefly later, but only insofar as the public policy being protected is "clearly established," which is in practice a significantly reduced subset. 
States because of government's ability to trample individual liberty, Blades argued, corporate power must also be checked. ${ }^{50}$

Although most academic critics of employment at will have favored a move to a good cause standard, at least as part of a proposal for reform, Blades did not, or at least he did not think it was realistic. ${ }^{51}$ Instead, Blades advocated a narrower form of protection designed to address what he saw as the worst effect of the employment-at-will rule: its threat to liberty. Blades argued for the establishment of a tort action of "abusive discharge" that would lie whenever an employer dismissed an employee in a way that "unreasonably attempts to interfere with [the employee's] personal freedom," 52 when an employee is "discharged as a result of resisting his employer's attempt to intimidate or coerce him in a way which bears no reasonable relationship to the employment." ${ }^{\text {3 } 3}$ The proposal that I advance in this Article is, in a sense, a return to the spirit of Blades's pioneering critique-a proposal for a limited revision of the at-will rule to correct its worst injustices. The difference is one of emphasis: Blades emphasized the threat to individual freedom, while I emphasize the threat to the individual's ability to maintain her living standard.

Writing a decade after Blades, Summers argued that a system in which unionized employees received just cause protection and non-unionized employees were left "totally vulnerable to arbitrary or malicious discharge" ${ }^{154}$ was unjust. ${ }^{55}$ Summers saw the just cause protection in the unionized sector as recognition that employees do have property rights in their jobs, that the "employee owns the job." Summers claimed that "protection against unjust dismissal [in the unionized sector] ... has earned acceptance as an essential element of a tolerable and humane employment relation"57 because "[f]or most employees, their job is the most valuable thing they possess," ${ }^{58}$ and that it should not matter whether one is a member of a union. Summers also emphasized that the United States was out of step

50. See id. at $1404-34,1435$.

51. See id. at 1433-34.

52. Id. at 1421-22. As described below, many courts have developed a tort of wrongful discharge against public policy. This tort is coextensive to some extent with Blades' tort of abusive discharge, but Blades's tort, with its focus on the harm to the individual employee as opposed to extrinsic societal policies, would protect many more employees.

53. Id. at 1413 .

54. Clyde W. Summers, Individual Protection Against Unjust Dismissal: Time for a Statute, 62 VA. L. REV. 481, 482 (1976).

55. See id. at 532 .

56. Id. at 506 .

57. Id. at 520 .

58. Id. at 532 . 
with other Western nations, ${ }^{59}$ which offered substantial employment security protections to their citizens. ${ }^{60}$

Legal academics have continued to attack the employment-at-will rule, often building on Summers's idea of the job as property. ${ }^{61}$ Donald Hermann and Yvonne Sor, for example, have justified the idea of a property right based on a Lockean natural law idea that the investment of labor (which belongs to the laborer) in the employer's enterprise increases the wealth of the employer more than the amount he pays the employee in wages; a property right in the job would compensate the employee for the difference. ${ }^{62}$

Other scholars have focused on the harm to employees. Theodore St. Antoine, in 1988, emphasized the enormous costs to employees who lose their jobs, including "increases in cardiovascular deaths, suicides, mental breakdowns, alcoholism, ulcers, diabetes, spouse and child abuse, impaired social relationships, and various other diseases and abnormal conditions." ${ }^{163}$ Although St. Antoine believed that Epstein's efficiency arguments suffered from an "Oz-like air of unreality," Epstein is right ... this piercing hurt to individuals ... justifies the call for reform of the at-will doctrine." 55 St. Antoine saw the elimination of "unjust dismissal" as a "moral and historical imperative." 66

Finally, scholars emphasize the unique place that employment plays in people's lives and the unfairness and inhumanity of subjecting people to undeserved termination. Arthur S. Leonard writes that the employment-atwill rule is inconsistent with the already highly-regulated employment relationship ${ }^{67}$ and that "entitl[ing] all discharged employees to an explanation related to their work performance or economic needs of the employer ... would accord with contemporary notions of respect for human dignity which underlie much of the evolving statutory employment law." 68

Pauline Kim's empirical data, which show that most employees think they have more legal protections than they actually do, call into question the Epsteinian economic defense of the employment-at-will rule, which is

59. See id. at $483-84$.

60. See id. at 508-19.

61. See id. at 532 .

62. See Donald H.J. Hermann \& Yvonne S. Sor, Property Rights in One's Job: The Case for Limiting Employment-at-Will, 24 ARIz. L. REV. 763, 767-68 (1982).

63. See Theodore J. St. Antoine, A Seed Germinates: Unjust Discharge Reform Heads Toward Full Flower, 67 NEB. L. REV. 56, 67 (1988).

64. Id.

65. Id.

66. Id. at 81 .

67. See Arthur S. Leonard, A New Common Law of Employment Termination, 66 N.C. L. REV. 631,675 (1988).

68. Id. at 680 . 
premised on the claim that employees would negotiate for good cause protection if they really wanted it. ${ }^{69}$ Why negotiate for something that you already have? ${ }^{70}$

Almost all scholars who have proposed reforming employment termination law have advocated replacing the employment-at-will rule with good cause protection or something very similar. ${ }^{71}$ Summers was the first to propose comprehensive statutory reform. ${ }^{72}$ The basic outline of his proposal was that all employees, ${ }^{73}$ after serving a six-month probationary period ${ }^{74}$ would be protected from dismissal or serious discipline ${ }^{75}$ for which the employer did not have "just cause." general understanding as to what 'just cause' means" "77 under collective bargaining agreements would be applied to statutory wrongful discharge cases. St. Antoine articulated a very similar proposal, ${ }^{78}$ as did Hermann and Sor, ${ }^{79}$ although the latter would exclude "top corporate executives" from coverage. ${ }^{80}$ Arthur Leonard advocates what he calls a presumption of "extended employment,"81 and Michael Phillips argues that "employees

69. See Kim, supra note 43

70. See id. at 147. But see Jesse Rudy, What They Don't Know Won't Hurt Them: Defending Employment-At-Will in Light of Findings that Employees Believe They Possess Just Cause Protection, 23 BERKELEY J. EMP. \& LAB. L. 307, 341 (2002) (arguing that employee ignorance of the at-will rule is "rational," as it would be a waste of effort to be familiar with the law of employment termination when the likelihood of being fired arbitrarily is extremely low).

71. See, e.g., Summers, supra note 45, at 521; St. Antoine, supra note 63, at 71-81; Hermann \& Sor, supra note 62, at 817-19; Robert M. Bastress, A Synthesis and a Proposal for Reform of the Employment-at-Will Doctrine, 90 W. VA. L. REV. 319, 346 (1988); Stephen F. Befort, Labor and Employment Law at the Millennium: A Historical Review and Critical Assessment, 43 B.C. L. REV. 351, 424 (2002); Ellen Rust Peirce, Richard A. Mann \& Barry S. Roberts, Employee Termination at Will: $A$ Principled Approach, 28 VILL. L. REV. 1, 45-46 (1982).

72. See Summers, supra note 45 , at 521.

73. Summers would allow employers and employees to contract around the statute's good cause right in certain limited circumstances, if the employees were given substantial definite term contracts. See id. at 525,526 .

74. Id. at 524-25. Summers contemplates that the probationary period could be longer in certain cases. Id. at 525 .

75. See id. at 526-27.

76. See id. at 520 . In the case of economically-motivated layoffs, employers would have to have a rational basis for deciding to lay off a particular employee, as opposed to a different employee. Id. at 527 (stating that " $[\mathrm{t}]$ he standard need not be a strict seniority system, but might include factors of age, training, breadth of skill, past productivity, and family responsibilities, so long as the factors are relevant, capable of objective measurement, and systematically applied.").

77. Id. at 521.

78. See St. Antoine, supra note 63, at 71-81.

79. Hermann \& Sor, supra note 62, at 817-19.

80. See id. at 814-15, 819

81. Leonard, supra note 67, at 682. 
have a moral right to be discharged only for good cause, [but they should be allowed to] contract that right away." 82

\section{The Dilution of Employment at Will}

Whatever the scholarly view of employment at will and what should replace it, legislatures and courts have done something that no scholar supports. They have created piecemeal exceptions to the at-will rule in a hodgepodge of statutes and common law rulings. Although one scholar has predicted the at-will rule's "impending death" based on the increasing number of exceptions, ${ }^{83}$ a powerful ghost still looms. The law governing employment termination lies somewhere along a continuum between at-will and good cause, but no one can say precisely where. And to the extent that we can say where the law is, it is hard to say why, and it would be foolhardy to rest assured that it will stay there.

The various exceptions have been well described elsewhere. ${ }^{84}$ I offer a brief description here for the sake of completeness and so that the reader can see how today's at-will rule is full of holes. The first exception was enacted in 1935 as part of the federal National Labor Relations Act. The architects of the NLRA understood that the right of employees to organize and form labor unions would be meaningless if union organizers or supporters could be fired for their pro-union activities before a collective bargaining agreement was reached. Thus, the NLRA made it unlawful to fire employees for engaging in collective action. ${ }^{85}$ Congress has also enacted a series of statutes prohibiting private employers from undercutting the national commitment to the equality of all citizens by firing workers based on race, sex, and other protected characteristics. ${ }^{86}$ State legislatures have moved to protect people from being fired based on characteristics, such as sexual orientation, that Congress has not protected. ${ }^{87}$ Also, states have enacted a variety of whistleblower protection laws that make it

82. Michael J. Philips, Toward a Middle Way in the Polarized Debate Over Employment at Will, 30 AM. BUS. L.J. 441, 444 (1992). Another common element of reform proposals is the idea of having employment termination disputes decided by some kind of non-judicial adjudication method, giving enforcement over to arbitration panels, see Summers, supra note 45, at 521-23, or administrative agencies, see Blades, supra note 33, at 1433, of one kind or another.

83. See Deborah Ballam, Employment-at-Will: The Impending Death of a Doctrine, 37 AM. Bus. L.J. 653 (2000).

84. See, e.g., Leonard, supra note 67 , at $640-63$.

85. See 29 U.S.C. $\S \S 158(a)(1),(3)(2000)$.

86. See, e.g., 42 U.S.C. $\S 2000 \mathrm{e}-2(\mathrm{a})(1)$ (2000) (Title VII of the Civil Rights Act of 1964); see also Charles A. Brake, Jr., Note, Limiting the Right to Terminate at Will-Have the Courts Forgotten the Employer?, 35 VAND. L. REV. 201, 203 n.10 (1982) (citing many examples of federal protections).

87. See, e.g., Minn. Stat. §363A.08 (2004). 
unlawful to fire an employee in retaliation for her reporting the employer's illegal conduct to authorities. ${ }^{88}$

Motivated perhaps by the concerns raised by academics, state courts have used common law contract and tort principles to chip away at the employment-at-will rule. ${ }^{89}$ Many courts, for example, have recognized a tort of "wrongful discharge" when the discharge is contrary to public policy, ${ }^{90}$ such as when employees are fired for refusing to commit perjury, ${ }^{91}$ serving on juries, ${ }^{92}$ whistleblowing, ${ }^{93}$ or engaging in political speech. ${ }^{94}$ The breadth of this wrongful discharge tort varies tremendously. In one scholar's view, a few states "have, for all intents and purposes, adopted the position that a cause of action arises anytime a termination is based on ... anything that undermines the broad notion of public good as defined by the courts, ${ }^{, 95}$ something close to Blades's abusive discharge tort. ${ }^{96}$ But most states require that the violated public policy is "clearly established" in a statute, constitution, or other specific source of law. ${ }^{97}$

Courts have also stretched contract principles to limit the right to fire. Although early decisions held that an employers' right to fire could be limited only if they had contractually agreed to a specific durational term, courts have been willing to interpret less than definitive statements as establishing such a contractual agreement. ${ }^{98}$ Many courts have also been willing to find evidence in employee handbooks and policy manuals that the employer has contractually bound itself not to fire at will, ${ }^{99}$ but in a legalevolutionary arms race, employers have learned to evade such a finding by putting disclaimers of contractual intent in handbooks. ${ }^{100}$ Terminated employees have also urged courts with occasional success to hold that the covenant of good faith and fair dealing, which is implied by law in every contract, means that termination may be for good cause only. ${ }^{101}$

88. See Elletta Sangrey Callahan \& Terry Morehead Dworkin, The State of State Whistleblower Protection, 38 AM. BUS. L.J. 99, 100, 107, app. (2000).

89. A good comprehensive description of the common law limitations on the employment at will doctrine can be found in St. Antoine, supra note 63, at 59-64.

90. See Brake, supra note 86, at 210-22 (describing the development and use of this doctrine).

91. See, e.g., Petermann v. Int'l Bhd. of Teamsters, 344 P.2d 25, 27 (Cal. Ct. App. 1959).

92. See, e.g., Nees v. Hocks, 536 P.2d 512, 517 (Or. 1975).

93. See, e.g., Sheets v. Teddy's Frosted Foods, Inc., 427 A.2d 385 (Conn. 1980).

94. See, e.g., Novosel v. Nationwide Ins. Co., 721 F.2d 894 (3d Cir. 1983).

95. Ballam, supra note 83 , at 685

96. See id.

97. See Ballam, supra note 83, at 664; Clyde W. Summers, Employment at Will in the United States: The Divine Right of Employers, 3 U. PA. J. LAB. \& EMP. L. 65, $73-74$ (2000).

98. See, e.g., Toussaint v. Blue Cross \& Blue Shield of Mich., 292 N.W.2d 880 (Mich. 1980).

99. See, e.g., Woolley v. Hoffmann-La Roche, Inc., 491 A.2d 1257 (N.J. 1985).

100. See Summers, supra note 97 , at 75 .

101. See id. at 72 (citing inter alia Monge v. Beebe Rubber Co., 316 A. 2 d 549 (N.H. 1974); Foley v. Interactive Data Corp., 765 P.2d 373 (Cal. 1988)). 
It is difficult to say what has motivated legislatures and courts to move away from the at-will rule in this limited fashion. To be sure, many exceptions to the rule vindicate important social policies such as protection of racial minorities and whistleblowers, and others purport simply to apply tort and contract principles to the employment relationship. But the haphazard nature of the exceptions and courts' applications of them also suggests that the exception doctrines are embraced and stretched by courts eager to correct what they see as unjust firings. In this view, the exceptions are resisted and narrowed by courts more sympathetic to employers. The result of this doctrinal tug of war is that employers and employees find it difficult to predict whether a given termination will stand up to judicial scrutiny.

As a result, the incursions on the employment-at-will rule have left no one happy. ${ }^{102}$ The absence of a bright-line rule and the possibility of large jury awards make many employers afraid to fire even poor performers. Employers often complain that the various statutory and common law exceptions to the employment-at-will rule have created so many potential claims that they are afraid to fire anyone and must waste substantial resources keeping detailed records about employees so as to have evidence to support a potential firing. If these complaints are valid, and if employers are indeed offering something like good cause only termination already, perhaps the enemies of at-will have won. But this claim is not true. In reality few employees are actually protected by the limited common law exceptions, ${ }^{103}$ and although some employers might be reluctant to fire, many others are not. And any victory obtained by a series of common law incursions may be pyrrhic, as some state legislatures have begun to override some of the common law incursions. ${ }^{104}$ As St. Antoine writes, "the present common law system ill serves all parties ...."105

The common law and statutory exceptions have gone far beyond what the defenders of employment at will view as justified by market failure and not nearly far enough for the scholars who believe that employees have a right to keep their jobs as long as they have not given good cause to be fired. Employers find the current landscape of employment termination law difficult to navigate and have reacted with extreme defensive measures to minimize the risk of lawsuits. These defensive measures include criminal background checks, credit searches, personality testing, involving human

102. See Theodore J. St. Antoine, The Making of the Model Employment Termination Act, 69 Wash. L. Rev. 361, 364-65 (1994).

103. See id.

104. Arizona, for example, enacted a statute in 1996 that among other things prohibits courts from declaring the at-will presumption overcome by contract unless the contract is in writing. See Ariz. Rev. Stat. Ann. § 23-1501(2); Marzetta Jones, Note, The 1996 Arizona Employment Protection Act: A Return to the Employment-at-Will Doctrine, 39 ARIZ. L. REv. $1139,1152-53$ (1997).

105. See St. Antoine, supra note 102, at 365. 
resources professionals and lawyers to document disciplinary matters in great detail, failing to fire poor performing employees who deserve to be fired and who are creating extra work for other employees, and enacting inflexible rules and policies that damage the human relationships in the workplace. These defensive measures are extremely expensive and demoralizing to employers and employees alike. Most employees, on the other hand, probably feel no more or less secure than they would without these protections; Pauline Kim's data suggest that most employees think they have more protection than they actually do, and the ones who know the law probably realize that they would have a hard time finding a lawyer and winning a case even if they were fired under questionable circumstances.

\section{E. Reform of Employment Termination Law}

The alternatives to the current termination law mess would appear to be: (1) to scale back the various exceptions, returning to something much closer to pure employment at will; (2) to move to a good cause standard, as the scholarly critics of the at-will rule have proposed; (3) to strike a compromise somewhere along the continuum between at-will and good cause, a position that can be described with precision even if it cannot be justified by any principle more inspiring than the spirit of peace; or (4) to discover a third way, a principled alternative to at-will and good cause that grows out of an effort to understand the basic nature of the employment relationship and what is at stake for the parties to it. The first three options have been tried in various ways, with little real success.

Some state legislatures have tried to scale back the judicial incursions on the at-will rule. Although they often enact these initiatives claiming to be returning to employment at will, the truth is that they are rather limited returns. It is hard to put a genie back in a bottle.

At the same time, prospects are exceedingly dim that any state will adopt the kind of good cause standard that at-will's scholarly opponents want. Only one state, Montana, has replaced the employment-at-will rule and its common law exceptions with a good cause standard, ${ }^{106}$ but Montana's system is much more of a compromise than a true good cause regime. The Montana Wrongful Discharge from Employment Act (WDEA) establishes a mandatory good cause rule for terminating employees who have completed a probationary period and do not have a fixed-term employment contract. ${ }^{107}$ Although at first glance the statute may

106. See Wrongful Discharge from Employment Act, MONT. CoDE ANN. §§ 39-2-901 to 904 (2005)

107. See id. $\S 39-2-904$. The statute supplies a default probationary period of six months, but employers may adopt probationary periods of different lengths. See id. $\S 39-2-904(2)$ (b). During the probationary period, employment may be terminated at will. See id. $\S 39-2-904(2)$ (a). Good cause in 
appear to be a major victory for employees, it actually arose as part of a tort reform movement after Montana juries began awarding large sums to terminated employees using the common law exceptions to the at-will rule. ${ }^{108}$ The statute's combination of a good cause rule and its restriction of remedies and preemption of common law torts means that more terminated employees have a cause of action but that those who would have had a case under the old system will obtain a far smaller award.

The National Conference of Commissioners on Uniform State Laws proposed an overt compromise in 1991 called the Model Employment Termination Act ("META"), a comprehensive reform proposal that, like the Montana statute, gives employees good cause protection that is undercut by numerous exceptions, caveats, and limitations on remedies. Theodore St. Antoine, the reporter for the committee that drafted META, describes the model statute as a compromise between pro-employee and pro-business interests. ${ }^{109}$ St. Antoine writes that META was motivated as much by a desire to stop the courts from establishing what employers feared would become a de facto good cause rule as by a desire to increase employee protection. $^{110}$ Thus, although META embraces the good cause alternative for which at-will opponents have been advocating, many of its provisions limit this protection. A decade and a half after its promulgation, META has not been adopted by a single state, and prospects for it to become law in all fifty appear dim in the extreme.

Montana means either poor employee performance or a "legitimate business reason." See id. § 39-2903(5).

108. See Michael H. Gottesman, Rethinking Labor Law Preemption: State Laws Facilitating Unionization, 7 YALE J. ON REG. 355, $368 \mathrm{n} .57$ (1990). Three features of the statute are designed to reduce employee awards. First, the statute limits the remedies available to wrongfully discharged employees to up to four years' lost wages and benefits, plus interest, reduced by earnings the employee has found elsewhere (or "could have earned with reasonable diligence"). See MONT. CODE ANN. § 392-905(1). Punitive damages are available only when the employee was fired for refusing to violate public policy or for reporting a violation of public policy and clear and convincing evidence shows "actual fraud or actual malice" on the part of the employer. See id. $\S 39-2-905(2)$. Second, the WDEA preempts all common law torts and implied contract claims connected with employment termination. See id. $\S 39-2-913$. Third, the statute pushes the parties into arbitration by providing that a party who refuses an offer of arbitration and loses in court must pay the other party's attorney fees. See id. $\S 39-2$ 915. Although some employees benefit from easy access to arbitration-namely, those whose salaries are too low for attorneys to take their cases on a contingency fee basis-arbitrators are thought to be, on balance, more pro-employer than judges and juries and less likely than juries to be swayed by sympathetic plaintiffs. Employers are repeat players in the arbitration arena, and arbitrators might unconsciously seek to please the party more likely to refer business to them in the future.

109. See St. Antoine, supra note 102, at 382.

110. See id. at 367. 


\section{META's Provisions}

META eliminates the at-will presumption for full-time ${ }^{111}$ employees who have served longer than one year. Such employees may be terminated only for good cause, ${ }^{112}$ defined to include poor performance ${ }^{1 / 3}$ and the employer's economic circumstances. ${ }^{114}$ META preempts most common law claims. ${ }^{115}$ Under META, employers and employees may, through written agreements, contract around the good cause requirement, either by defining good cause more specifically ${ }^{116}$ or by allowing termination at will. The latter is permissible only if the employer agrees to a severance payout of one month's pay for every year worked. ${ }^{117}$

META's first-line remedy for wrongful termination is reinstatement. ${ }^{118}$ According to St. Antoine, "returning wrongfully discharged employees to their old jobs ... [is] the primary goal" because "in the long run an employee is likely to benefit more from a restored opportunity to exercise acquired skills" than from money damages. ${ }^{119}$ If an employee is fired without good cause, the employee can be reinstated and awarded backpay and attorneys' fees, the same remedies as are available under Title VII. ${ }^{120}$ If reinstatement is "impracticable," the employer can be required to pay up to 36 months' pay as "severance pay," 121 but generally the severance pay would be much less. ${ }^{122}$

Proponents of META describe it as a "fair and practical compromise between the competing worthy interests of employers and employees."

111. META defines full-time as twenty hours or more per week. See Theodore J. St. Antoine, The Model Employment Termination Act: A Fair Compromise, 536 ANNALS AM. ACAD. POL. \& SOC. SCI. 94, 97 (1994). META applies only to employers with five or more employees. See id.

112. See id.

113. The arbitrator's review is "essentially objective." Id. at 97 . The bad act or deficient performance claimed by the employer must be true and "serious enough to warrant dismissal." Id.

114. See St. Antoine, supra note 102, at 371-72; Stanley M. Fisher, Legislative Enactment Process: The Model Employment Termination Act, 536 AnNALS AM. ACAD. POL. \& SOC. SCI. 79, 85 (1994). The employer must make a "good-faith business judgment" that economic circumstances warrant a dismissal. St. Antoine, supra note 59, at 97 . The reviewing arbitrator looks only at whether the employer exercised good faith-that is, whether the claim of economic reasons was a pretext-not to whether the employer made an accurate assessment of the economic circumstances. See id.

115. See Model Employment Termination Act $§ 1(2)$, 7; St. Antoine, supra note 59, at 98.

116. See Model Employment Termination Act $\S 4(\mathrm{~b})$.

117. See id. $\S 4(\mathrm{c})$. The severance pay need not be given to the employee if the termination was due to the employee's "willful misconduct." See id.

118. See id. § 7(b)(1).

119. See St. Antoine, supra note 102, at 375.

120. See Model Employment Termination Act § 7(b)(1)-(2) (2005); St. Antoine, supra note 102, at 375 .

121. See Model Employment Termination Act $\S 7(b)$ (2005).

122. See id. $\S 7(\mathrm{~b})(3)$; St. Antoine, supra note 102, at 375 . The full three years of pay, however, would be reserved for "the most egregious violations." St. Antoine, supra note 59, at 98.

123. St. Antoine, supra note 59 , at 96 
St. Antoine emphasizes that workers get a right to employment security in return for giving up the unlikely but possible damage awards available under the common law. ${ }^{124}$ META's mandatory arbitration scheme is also meant to give everyone a fast and cheap way to resolve claims. ${ }^{125}$

\section{Criticism of META}

META has been much criticized and little praised in the legal academy. Neither side in the debate over the employment-at-will rule has much good to say about it. Calling it a "toothless tiger," 26 Kenneth A. Sprang argues that META will not accomplish its purpose; the relatively minimal remedies META allows-especially when compared to tort damages-are insufficient to compensate wrongly terminated employees or to deter bad behavior by employers. ${ }^{127}$ Employers, he writes, "may see the claims of such employees as nothing more than minor inconveniences, a cost of doing business." 128 The minimal remedies, combined with the two ways in which META allows its default rules to be circumventedretaining at-will in return for severance agreements and allowing employers essentially to modify the meaning of "good cause" by adopting extremely demanding performance standards ${ }^{129}$ — make META an ineffective means to ensure job security. ${ }^{130}$ Sprang also criticizes META's emphasis on reinstatement - its primary goal, according to St. Antoine-because "[i]t simply does not work." 131 Sprang cites studies that show that reinstated employees generally leave within one year. ${ }^{132}$

Sprang believes that a statute requiring good cause should not defer to an employer's definition of performance standards; performance standards "should be subject to a reasonableness standard."133 Employers and employees should not be allowed to contract around META's good cause standard, ${ }^{134}$ and employees should receive at least thirty days' notice prior to termination, Sprang says, to "allow the employee to pursue internal grievance remedies before leaving his employment, as well as to provide

124. See id.

125. See id.

126. Sprang, supra note 9 , at 858 .

127. See id. at 902 .

128. See id. at 902-03. Sprang cites the addition, in the Civil Rights Act of 1991, of compensatory and punitive damages to the already available reinstatement and back pay remedies as an instance of legislative recognition that contract-like remedies are inadequate as compensation or as deterrents. See id. at 916-18.

129. See id. at 895 (citing Model Employment Termination Act $\S 1 \mathrm{cmt} .4$ ).

130. See id. at 902-04.

131. Id. at 920 .

132. See id.

133. Id. at 921 .

134. See id. The exception would be a fixed-term contract. See id. 
the discharged employee some opportunity to seek new employment before his old employment terminates."135

META has been met with equal hostility in pro-employer circles. One opponent says that META's language is too vague, which would make its application unpredictable, ${ }^{136}$ thus failing to solve one of employers' biggest problems under the current system. Despite its various limitations on the good cause principle, META represents an enormous change for employers. Employers who do not execute good cause waivers with their employees lose their freedom to fire without exposure to substantial damages. Such employers cannot fire even poor performers without serious risk of being sued for wrongful discharge. Employers who do obtain waivers are forced to choose between retaining employees they no longer want and making very large severance payments. It is obvious that META reduces employer flexibility and distorts the economics of hiring and firing.

Like the current system, no one appears happy with META. Perhaps this dissatisfaction grows out of an inability to justify META as anything more than the product of a committee's haggling. St. Antoine emphasizes the practical compromises required in the drafting process rather than a philosophical basis for META's allocation of rights and restriction of remedies. ${ }^{137}$ In describing the drafting process, he often writes of "battles" within the drafting committee that were won by advocates of one side or the other. ${ }^{138}$ "The model act," he writes, "may not be any one person's ideal solution to the evils of at-will employment. Its transcendent virtue, however, is that it has emerged from the fire of three years' intense scrutiny and reshaping by a prestigious body of sophisticated legal artisans, practically none of whom had any partisan cause to promote. META is unabashedly a compromise ...."139

\section{F. A New Hope: Employment at Will with Mandatory Pretermination Notice}

Perhaps an unabashed compromise is the wrong approach. Why move from one unexplainable system to another? The current state of employment termination law is unacceptable to both sides, and all three alternatives on the table-a return to Epsteinian employment at will,

135. Id. at 921-22. It is, of course, my contention that pretermination notice should be the only change made to the at-will rule. I agree with Sprang about the advantages of notice.

136. See Mary Jean Navaretta, The Model Employment Termination Act-META-More Aptly the Menace to Employment Tranquility Act: A Critique, 25 STETSON L. REV. 1027, 1030 (1996).

137. See, e.g., St. Antoine, supra note 59, at 96 (describing resistance to the idea of the act at the Uniform Law Commissioners' annual meeting); id. at 97 ("In a major concession to employers, compensatory and punitive damages are expressly excluded. But $\mathrm{I}$ think this is a fair exchange for establishing an employee's substantive right to a job, absent good cause for dismissal.").

138. See, e.g., St. Antoine, supra note 102, at 375.

139. St. Antoine, supra note 59, at 102. 
adoption of de facto tenure under a good cause standard, and the split-thedifference compromise represented by META and by Montana's statuteappear to be non-starters. It is time to look for another solution.

What would such a solution look like? Ideally, it would accord with the principle that people should be treated better than objects, that there is something unjust - whatever the rational or economic justification-about a person's livelihood being completely at the mercy of another. A solution to the employment termination problem would also accord with the principle that employers should not be stuck forever with workers they no longer want, especially if those workers could find another job. Good cause does not accord with this principle or with the need for staffing flexibility in a competitive market. It seems unjust to construct the law in such a way that an employer may never fire someone unless she can prove objective fault. The law should allow human beings to part ways.

What sort of rule would satisfy both principles - that it is unfair to subject one person's livelihood to the whim of another and that it is unfair to force a person to maintain a relationship with another against his will? Such a rule would have to allow the parties the freedom to end their relationship for any reason and at any time, ${ }^{140}$ but it would also restrict the manner in which the relationship could be ended so as to minimize the suffering of the weaker party.

Requiring an employer to give an employee enough notice of impending job loss to allow the employee to find a new job before losing the old one would satisfy both principles. If we knew that a fired employee could get another job that was basically just as good, paid just as much, provided as much personal satisfaction, and allowed him to use his skills and develop new ones, our sense of injustice would be minimized. The fact that the individual was fired arbitrarily or unfairly should not matter very much. ${ }^{141}$ The main problem with job loss is not so much the job loss itself but the difficulty of finding another job and the devastating human and economic cost of joblessness. Thus, a solution that gives an employee a permanent property right in a particular job is overkill, but a solution that gives an employee a temporary right to keep her job until she finds a new one seems much more fair, at least as long as this right is balanced against the employer's needs.

This Article offers such a proposal. I believe that this proposal has a better chance of being adopted than any other because it accords with our intuitive sense of what is wrong with both employment at will and with good cause, maximizes the benefits and minimizes the harms to both

140. The parties' freedom could be limited by society's interests-for example, society's interest in prohibiting the use of race as a factor in any sort of public or private decision-but not by the interests of the individuals in the relationship.

141. See Power, supra note 19 , at 892. 
employers and employees, and flows from a principled reconceptualization of the very nature of the employment relationship rather than a backroom compromise. It is to the principle behind the proposal that I turn to in this next Part.

III.

From SALE OF LABOR To LEASE OF HUMAN CAPITAL

The attacks on and defenses of the employment-at-will rule involve two very different conceptions about the nature of the employment relationship. The conception of work as a marketable commodity like any other leads its adherents to support the employment-at-will rule, while the conception of employment as intimately intertwined with human dignity leads its adherents to assert that employees should lose their jobs only when the employer has good cause to fire them. If the proposed legal rules that emerge from these two conceptions strike nearly everyone as wrong, perhaps the description of the nature of the relationship is wrong as well.

Although human dignity is deeply intertwined with work, I also acknowledge that employee labor is and, at least to some extent, must be treated as a commodity by employers. Thus, we cannot look at the employer-employee relationship as solely a human relationship. But to say that a relationship is an economic one is not necessarily to say all that much. There are different kinds of economic relationships, and the law treats different economic relationships in different ways.

Supporters of the at-will rule view the employment relationship as a sale of labor by employees to employers, and they believe that the law should not treat employment differently from any other purchase and sale relationship; parties cannot be forced to continue to buy from and sell to one another if they no longer want to and have not contracted to do so. Opponents of the at-will rule have not claimed that the employment relationship better resembles another type of economic relationship; rather, they have asserted that justice and a respect for human dignity require extraordinary treatment of the employment relationship and the granting to employees of property rights in their jobs. To argue that a relationship should be treated profoundly differently from other similar relationships is always difficult, as it is in tension with the value of treating like cases alike.

My claim is that the economic relationship most analogous to the employment relationship is the lease. The description of employment as a purchase and sale is wrong, and the granting of a property right in one's job is unnecessary to achieve a just solution to the employment termination problem. Employees already have property rights in the human capitaltheir income-generating potential-in which they have invested through education and experience over the course of their working lives. When an employee takes a job, this property is entrusted into the care of the 
employer; it is leased, and the employer pays rent in return for the use of the employee's human capital, which generates labor that the employer is free to use as he wishes. If employment is a lease, the employer should take on a limited duty to care for the employee's human capital-the employee's potential to generate income in the future-that is similar to an employer's duty to care for any other property that he might lease.

\section{A. Baselines}

The legal rules that a society chooses to govern a given transaction often depend on that society's understanding of the fundamental nature of that transaction; ${ }^{142}$ Jack Beermann and Joseph Singer refer to such societal understandings as "baselines." 143

In reflecting on employment termination law, Beermann and Singer argue that legal outcomes are often practically predetermined by such "baseline" conceptions about the nature of the employment relationship. ${ }^{144}$ They assert that important "unstated baselines" lead courts to "resolve conflicting claims between workers and management in favor of management" and "deemphasize the social costs of arbitrary firings and the social benefits of job security." ${ }^{45}$ These baselines "have the effect of creating a presumption against job security that is almost impossible to overcome" and that "effectively place the burden of proof on advocates for job security."146 By exposing the "suppressed moral and political questions underlying employment-at-will," 147 Beermann and Singer aim to show that options that might have seemed to be foreclosed were actually available. ${ }^{148}$

Most germane to this Article, Beermann and Singer discuss what they call the "social vision" that "plays itself out in . . presumptions regarding the nature of the agreement between the parties" to an employment relationship and "orient[s] our thinking." ${ }^{49}$ One area in which this social vision is influential, they write, is in the conception of property rights in the employment relationship.

The basic property-based vision of the employment relationship, according to Beermann and Singer, is that the employer grants the employee a license to come onto the employer's property and perform her

142. See Beermann \& Singer, supra note 18, at 913-14.

143. See id at 914 .

144. See id. Beermann and Singer cite Jeremy Paul, Cass Sunstein, and Duncan Kennedy for the initial work on the importance of baselines. See id. (citations omitted).

145. Id. at 916 .

146. Id. at 919 .

147. Id. at 916 .

148. See id. at 919 .

149. Id. at 937 . 
labor. ${ }^{150}$ In traditional property law, the owner can revoke such a license at any time. ${ }^{151}$ Thus, if we accept this baseline as the proper description of what is going on in the employment relationship, "workers' arguments in favor of job security are doomed before they can be made."152 Beermann and Singer propose alternative baseline conceptions that would grant the employee property rights in the job. The law often grants property rights to an apparent non-owner when equity or other social considerations demand it. As examples, they cite the law of adverse possession and the creation of the equity of redemption in mortgage law. ${ }^{153}$ Beermann and Singer believe that employees' dependence on their long-held jobs and other factors justify similar reallocations of property rights, making employees "'part-owners' of the workplace." 154 Alternatively, Beermann and Singer propose creating property rights in jobs themselves. ${ }^{155}$ Beermann and Singer also challenge many of the baselines that they believe support the economic efficiency arguments in favor of employment at will. ${ }^{156}$

I agree with Beermann and Singer's premise that employment termination law is built upon a particular set of usually unstated baseline conceptions about the fundamental nature of the employer-employee relationship. I agree also that the common understanding of the employment transaction as a purchase and sale of labor (that takes place on the employer's property) is not the most accurate way to understand the relationship. But rather than proposing the imposition by law of a new baseline that reallocates property rights, I argue for the more modest step of recognizing that viewing the employment relationship as a lease represents a baseline that accords better with most people's intuitions about what is just and unjust in that relationship.

It may be useful to point out here that the employment-at-will rule itself appears to be the outgrowth of a baseline shift. When the baseline understanding of employment was the master-servant relationship, the oneyear presumption made sense. ${ }^{157}$ In industrial nineteenth century America, however, master-servant no longer seemed to be the best analogy. ${ }^{158}$

150. Id. at 946

151. Id.

152. Id

153. See id. at 949-50. Jay Feinman makes a related point. Feinman points out that both the employment relationship and the landlord-tenant relationship are established by agreements between the parties, but the rules concerning the termination of these relationships are different because of different baselines: property law in the case of landlord-tenant and domestic relations in the case of employment. See Feinman, supra note 6, at 130.

154. See Beermann \& Singer, supra note 18 , at $953-54$.

155. See id. $954-56$.

156. See id. at $956-85$.

157. See id. at 920.

158. See id. at 921 . 
Instead, employers and employees were viewed as parties to one of the many arm's length contractual relationships that allowed business to produce goods and services at a profit. This Article suggests, however, that the purchase-and-sale baseline that replaced master-servant is not the best description of the true nature of the relationship, and the employment-atwill rule that emerged from that baseline is therefore flawed.

The baseline underlying the employment-at-will rule-the purchase and sale-is that employers grant employees a license to enter the workplace and generate units of labor that are sold to employers in return for what we call wages, fringe benefits, and other consideration. Because each payment of wages is simply compensation for the last set of labor units that an employee has sold to the employer, the relationship may be terminated at any time without violating the contract or property rights of either party. The baseline proposed by this Article is different: employees are owners of human capital, which is what allows them to produce units of labor. Employers lease this human capital in return for wages and benefits. This lease creates a bailment-like relationship, in which employers control and have the power to damage the value of employees' human capital. Employers thus acquire a duty to care for the employees' human capital and are responsible for avoidable damage to it.

\section{B. Human Capital in Labor Economics}

Since the early 1960's, prominent economists, such as Theodore W. Schultz and Nobel Prize winner Gary Becker, as well as business and legal scholars, have viewed employees as investors in an asset that they have termed "human capital." 159 Capital, as economist Jacob Mincer explains, is "any asset that gives rise to an income stream."160 Because employees' wages are based on their productivity, "[a]ccumulated human work capacity qualifies as a capital asset in the same sense as physical capital even if it cannot be bought and sold (it is, of course, rented), and even though investments in such capital often involve non-market activities, such as education." 161

Individuals build up their human capital in a variety of ways. The most obvious way to acquire human capital is to invest in formal education. ${ }^{162}$ In deciding to forego the ability to work in order to attend school, individuals act like classic investors who give up the use of their

159. See generally Theodore W. Schultz, 51 AM. ECON. REV. 1 (1961); GARY BECKER, HUMAN CAPITAL: A THEORETICAL AND EMPIRICAL ANALySIS, With SPECIAL REFERENCE to EDUCATION (2d ed. 1975); THOMAS O. DAVENPORT, HuMAN CAPITAL: WHAT IT IS AND WHY PEOPLE INVEST IT (1999).

160. 1 JaCob MinCER, Studies in Human Capital: Collected EsSays of Jacob Mincer, at $x$ (1993) (citing IRVING FISHER, THE THEORY OF INTEREST (1930)).

161. Id.

162. See BECKER, supra note 159 , at 37-39. 
capital in the short term in order to build its value and receive greater returns in the long term. ${ }^{163}$ On-the-job training is also a major form of human capital investment. ${ }^{164}$ Gary Becker explains that acquisition of human capital on the job is a form of investment because employees accept lower wages than they could otherwise earn in exchange for on-the-job training that they expect will result in higher wages down the road. ${ }^{165}$ Human capital is made up of other factors and investments as well, such as "emotional and physical health." 166

No matter how it is acquired, this capital asset generates an income stream in the form of wages. As Mincer describes the modern perspective, "earnings at any time are seen as a return on the skill level-the humancapital stock embodied in the person and accumulated by him up to this time." 167 And "[s]ince the size of this capital stock grows over the life cycle by means of investment and declines because of depreciation and obsolescence, earnings change correspondingly." 168

The value of an employee's human capital-that is, whether an employee can find a renter and how much rent he can obtain - obviously depends not only on the skills, knowledge, and good health that he has, but also on his reputation for having these things. Just as an extremely productive piece of equipment will not produce returns for its owner if potential users of the equipment do not know what it can do or think it is broken, an employee's human capital loses value if the employee's reputation as a productive worker is harmed.

\section{Employment as a Lease of Human Capital}

If employees are investors in their own human capital, and if wages are viewed as rents, the employment relationship starts to look more like a lease than a sale. Although the conception of employees as investors in human capital is nothing new, the notion has not led the law to a new baseline understanding of the employment relationship. ${ }^{169}$ It is true that viewing

163. See 1 MINCER, supra note 160 , at 69 ; BECKER, supra note 159 .

164. See BECKER, supra note 159 , at 24

165. See id. at 24-26.

166. See id. at $40-41$.

167. 1 MINCER, supra note 160 , at 72 .

168. Id. at 72 .

169. A few legal scholars have brought the human capital concept into the employment termination debate. Stewart Schwab's work describes wages as return on human capital and justifies certain limitations on the employment-at-will rule with reference to human capital. See Schwab, supra note 42. Katherine Stone has written extensively on human capital, but not in relation to the employment-at-will rule. Stone, exploring current labor economics and management theory literature, asserts that a "new psychological contract" has taken hold in the United States. Katherine V.W. Stone, The New Psychological Contract: Implications of the Changing Workplace for Labor and Employment Law, 48 UCLA L. REV. 519 (2001) [hereinafter Stone, Contract]; Katherine V.W. Stone, Knowledge at Work: Disputes Over the Ownership of Human Capital in the Changing Workplace, 34 CONN. L. REV. 721 
employees as investors in their own human capital can still be consistent with the baseline understanding of the relationship as a purchase and sale of labor; in this view, the employee invests in and builds up his human capital, uses the human capital to generate labor, and then sells that labor to an employer in return for wages. But there are two other baselines that are also consistent with the conception of employees as human capital investors. One conception is that the employees invest their human capital in the company when they take a job and that this human capital investment is analogous to the financial capital invested by shareholders. This idea has been explored by Katherine Van Wezel Stone ${ }^{170}$ and would support the imposition of some sort of fiduciary duties owed by a firm to its employees. ${ }^{171}$

A second alternative baseline that is consistent with the human capital idea-and that I believe fits it best-is that the employment relationship is a form of lease, similar to an equipment lease. This view, which has not been explored in the legal literature, accords with the economists' descriptions of human capital as being rented by employers.

A lease is a "contract by which the rightful possessor of personal property conveys the right to use that property in exchange for consideration." 172 When someone leases another person's property, ownership of that property is not transferred, but possession and control are temporarily transferred to the lessee. The distinction between leasing a piece of equipment and purchasing the outputs of a piece of equipment

(2002). A psychological contract is the implicit set of understandings that aligns employer and employee interests, giving employees incentives to give their best efforts and invest in firm-specific training. See Stone, Contract, supra, at 524. The old psychological contract promised hard workers long-term employment and a path of continual advancement through the firm's internal hierarchy. See $i d$. at 535 . Because many companies, in order to survive in an increasingly competitive economy, have eliminated internal hierarchies and prefer just-in-time staffing models, the old psychological contract is no longer tenable for many employers. These employers, however, must still find ways to induce employees to give their best efforts and invest in training. The new psychological contract that has emerged promises good employees "employability security," see id. at 569 (citing ROSABETH MOSS KANTER, ON THE FRONTIERS OF MANAGEMENT 190 (1997)), instead of employment security: employees will receive training and will learn skills that are not primarily firm-specific and that will be useful to them in finding good jobs elsewhere after their tenures at their current employers end. See id. at 552. In essence, the new psychological contract means that employees are behaving even more like classic capital asset owners than they did in the past. Under the old psychological contract, much employee: human capital was firm-specific. Under the new psychological contract, general human capital, which is valuable to many employers, is becoming an increasingly important part of what employees seek to gain when they take a job-and what employers implicitly promise. Stone's work focuses on the growing use of post-employment restrictions by employers, which she believes violates the terms of the new psychological contract, and upon discrimination law and labor law statutes, which she sees as increasingly anachronistic. See id.

170. See Katherine Van Wezel Stone, Employees as Stakeholders Under State Nonshareholder Constituency Statutes, 21 STETSON L. REV. 45 (1991).

171. See id. at 48.

172. BLACK'S LAW DICTIONARY 907 (8th ed. 2004). 
comes down to whether the putative lessee can be said to be using or controlling the equipment itself or merely receives its output.

A purchaser acquires with that purchase the property right to treat the purchased goods in any way the purchaser deems fit, but a lessee receives only the right to possess and use the property of another. Because, at least in most leases, the lessor expects to retake possession of his property at the end of the lease, the law of bailment generally applies to leases and requires the lessee to exercise care over the property that does not belong to him. ${ }^{173}$ The lessee, in control of the lessor's property and using it for his own benefit, has the power to damage or destroy something that does not belong to him; the law of bailment imposes a duty on the lessee to treat the leased property with as much care as he would give his own property.

Employees place their human capital at the service and under the control of an employer, who uses it to generate labor inputs into the employer's profit-generating enterprise. Indeed, the question whether an employer has "the right to control the means and manner of the [employee's] service"174 has always dominated the common law determination of whether an individual is an employee or an independent contractor. The question whether the employer controls the means and manner of the employee's service-the very definition of whether someone is an employee-is just another way of asking whether the employer controls the means and manner in which an individual must use his human capital. It is therefore fair to say that a person who chooses to hire an employee-as opposed to giving a job to an independent contractor, the manner and means of whose work the employer has no right to control ${ }^{175}$ chooses to enter a lease-like relationship.

Just as the lessee's actions have the potential to damage the lessor's property and reduce its value, the manner in which an employer exercises his control over an employee's human capital has the potential to damage that capital and reduce its value. The most obvious example of the way in which an employer can damage an employee's human capital is by requiring him to perform his work in a dangerous location in which he could be injured. ${ }^{176}$ If the employment relationship is more like a lease than like a sale, the law should impose a bailment-like duty of care upon the employer.

173. See discussion infra Part III.D.

174. Chouteau v. Netco Construction, 132 S.W.3d 328, 332 (Mo. Ct. App. 2004) (quoting DiMaggio v. Johnston Audio/D\&M Sound, 19 S.W.3d 185, 188 (Mo. App. W.D. 2000), overruled on other grounds by Hampton v. Big Boy Steel Erection, 121 S.W.3d 220 (Mo. Banc 2003)).

175. See id.

176. The application of bailment duties to the employer-employee relationship outside the context of employment termination is beyond the scope of this Article, however it is a subject to which $I$ intend to turn in the future. 


\section{The Law of Bailments}

According to Black's Law Dictionary, a bailment is "[a] delivery of goods or personal property, by one person (bailor) to another (bailee), in trust for the execution of a special object upon or in relation to such goods, beneficial either to the bailor or the bailee or both, and upon a contract, express or implied, to perform the trust and carry out such object, and thereupon either to redeliver the goods to the bailor or otherwise dispose of the same in conformity with the purpose of the trust."177 Corpus Juris Secundum adds that "the very essence of a contract of bailment is that after its purpose has been fulfilled the bailed property shall be redelivered to the person who delivered it, or be otherwise dealt with according to his direction, or kept until he reclaims it, as the case may be. ${ }^{178}$

Although the common law has, of course, never yet gone so far as to say that the employer is a bailee of an employee's human capital, courts have on occasion held that a bailment relationship is formed between an employer and an employee as to goods owned by the employee but left under the control of the employer. The case of Harper v. Brown \& Root, Inc. ${ }^{179}$ provides an interesting example of such a bailment. Brown \& Root, a construction company, required its mechanic, Jimmy Harper, to supply his own tools. ${ }^{180}$ The tools weighed about 175 pounds, and mechanics customarily (and with the company's knowledge) left their tools at the job site, which was locked and guarded, at the end of the work day. ${ }^{181}$ One day, Harper came to work to find his tools missing. ${ }^{182}$ The Supreme Court of Louisiana held that a bailment relationship existed between Harper and his employer with regard to the tools, finding that "the consent of the parties $\ldots$ is implicit from the facts and circumstances" $" 183$ and that Harper was entitled to damages for his loss. ${ }^{184}$

One key to the court's holding in Harper was that only "some degree" of "possession and control" must be given to a bailee by a bailor. ${ }^{185}$ The facts that amounted to a finding that the employer exercised sufficient possession and control of the tools to constitute a bailment included that the employer required that the tools be on the job site, that the employer transported the tools on its truck, that the employee only removed tools from the employer's truck "as needed to perform employment duties," that

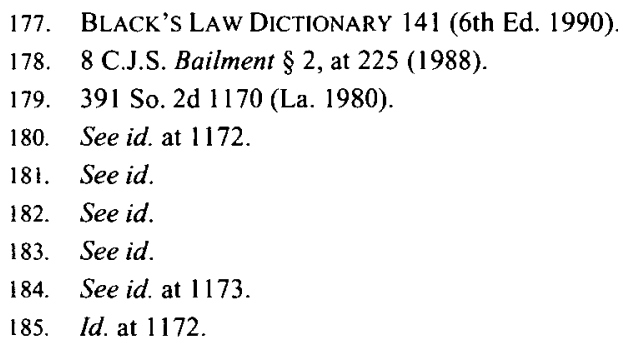


the employer provided twenty-four hour security at the job site, and that "neither party realistically expected that the employee was to reassume complete possession and control" of the tools at the end of the work day. ${ }^{186}$ The court held that "as a practical matter [the employee] was virtually required to leave his tools at the construction site and cannot reasonably be viewed as having done so for his own convenience as a matter of choice."187

When an employee takes a job, she is required to supply her own human capital in the same way that Jimmy Harper was required to supply his own tools. While the employee, like Harper, maintains some control over this human capital - she can injure it, for example, by adopting a bad attitude or increase its value by taking business courses in the eveningsthe employer also exercises substantial control over it. Indeed, as discussed above, such power is the core of the very definition of the employment relationship. The employer can injure the value of the employee's human capital by disciplining or demoting the employee, by requiring the employee to work under unsafe conditions, and he can injure it by firing her, and there is nothing that the employee can do about it. It is obvious that an employee does not "reassume complete possession and control" over the value of her human capital at the end of the work day.

The common law of bailments imposes increasingly substantial duties of care upon bailees as the benefit to the bailee increases and the benefit to the bailor decreases. Thus, when the bailee receives no benefit, such as when a friend allows another friend without charge to park her car in his garage for the winter, the bailee owes only a duty of "slight care," 188 which means that the bailee will be liable only for gross negligence. ${ }^{189}$ At the other extreme, when the bailment is for the exclusive benefit of the bailee, such as when a neighbor borrows a lawnmower, the bailee owes a duty of "great care," 190 which amounts to liability "for but the slightest neglect causing damage to the subject matter of the bailment." 191

In between is the sort of bailment that arises from a lease. When one party leases goods to another, both parties benefit--the lessor by receiving payment and the lessee by receiving the use of the goods. The bailment relationship that arises from a lease is thus known as a bailment for mutual benefit, and the law imposes upon the lessee/bailee a duty of "ordinary care"-that is, "that degree of care a man of ordinary prudence and

186. Id. at $1172-73$.

187. Id. at 1173 .

188. 8 C.J.S. Bailments $\S 69(2005)$.

189. See 8 C.J.S. Bailments $\S 70$ (2005) (describing gross negligence as "an omission of the care which even the most inattentive and thoughtless never fail to take of their own concerns") (citations omitted).

190. $8 \mathrm{id} . \S 73(2005)$. The bailor is not wholly without duties in such a situation; he must warn the bailee of known dangerous defects. See 8 id. $\S 44$ (2005).

191. Niagara Fire Ins. Co. v. Shuff, 93 So. 2d 325, 329 (La. Ct. App. 1957). 
discretion would use in reference to the particular thing were it his own property." ${ }^{192}$ In other words, the bailee must treat the property as if it were his own.

This duty of ordinary care is imposed upon the bailee as long as the bailee is in possession of the bailed property, and thus it extends to the "act and manner of returning the subject matter to the bailor." ${ }^{193}$ Even though a bailment for an unspecified term-known as a "bailment at will"-may be terminated at any time by the bailee, ${ }^{194}$ the bailee remains liable for damage to the property that occurs in the process of ending the bailment if the bailee has failed to exercise ordinary care. The common law translated the duty of ordinary care in bailment termination into a requirement that the bailee give the bailor "reasonable notice" before terminating the bailment. ${ }^{195}$ Such notice must be "of a positive and definitive character ... giving to the bailor a reasonable, but a certain fixed time within which to remove the goods ...." "196

The requirement that the bailee give the bailor sufficient notice for the bailor to make arrangements to remove the bailed property without damaging it is especially important in the case of bailed goods that are vulnerable to losing value in the process of the termination of the bailment. A straightforward example is that of a refrigerated warehouse that stores a farmer's milk until a refrigerated truck comes to bring the milk to market. The warehouse owner, even in the case of a bailment at will, may not simply make a deal with another farmer who agrees to pay more for milk storage, decide that the first bailment is over, and put the first farmer's milk out on the street causing it to spoil. Rather, he must notify the farmer that he intends to end the bailment and give the farmer a reasonable period of time in which to find alternative storage for his milk and arrange to transfer it.

An example from the world of biotechnology may be helpful in underscoring this point. In a 1989 case dealing with the disposition of frozen embryos, a federal district court held that there was a bailment relationship between an infertile couple and the in-vitro fertilization clinic that was storing the frozen embryos. ${ }^{197}$ Although the case dealt with a situation in which the clinic refused to surrender custody of the embryos to the couple, had the situation been reversed — that is, had the clinic decided

192. 8 C.J.S. Bailments $\S 57$ (2005). Because the bailee is not an agent of the bailor, this duty is not a fiduciary duty; rather it is an ordinary common law duty. The interests of the bailor and bailee may very well be divergent.

193. 8 id. $\S 61(2005)$.

194. See 8 id. $\S 100$ (2005).

195. See id.

196. Weinstein v. Sheer, 120 A. 679, 681 (N.J. 1923).

197. See York v. Jones, 717 F. Supp. 421, 425 (E.D. Va. 1989). 
unilaterally to stop storing the embryos-the bailment relationship would have required the clinic to give the couple sufficient notice to allow them to arrange to store the embryos at another site without damaging them.

\section{E. The Duty of Ordinary Care as Applied to Employment Termination}

Modern employers lease equipment on a regular basis. I have written this Article on a computer that my employer has leased from a leasing company. The requirement to take care of someone else's property is one that is familiar to employers. Granted, most equipment leases are probably governed by written contracts with fixed terms, but the point is that businesses are used to the idea that much of the equipment in the workplace belongs to someone else and will have to be returned to its owner in reasonably good shape at the end of the lease. Thinking about employment as a bailment of human capital represents merely a shift from one category of common economic transactions in which an employer frequently engages to another. As such, treating employment like a bailment would not introduce unfamiliar duties into the typical employer's world; it would simply require employers to exercise the same level of care over their employees that they already exercise over their equipment.

If the employment relationship is conceptualized as a lease of human capital, and employers owe employees a duty of ordinary care over their human capital, neither the pure employment-at-will rule nor a pure good cause rule is appropriate. Under the employment-at-will rule, the employer has no duty at all to protect the value of the employee's human capital, which is even less than the duty of slight care owed by a bailee who receives no benefit at all from the bailed property. An employer, however, receives substantial benefit from the employee's human capital. A good cause rule, on the other hand, would impose upon employers a duty at least as substantial as the duty of great care that is owed by a bailee in cases in which the bailee benefits from the bailed goods and the bailor benefits not at all. Such is clearly not the case in the employment relationship, in which the employee benefits not only by receiving wages, but also from getting work experience that increases to the value of her human capital.

If employment is a lease of human capital, the legal rule governing employment termination should be based upon the duty of ordinary care. The duty of ordinary care amounts to a requirement that the bailee/employer treat the bailor/employee's property as if it were the bailee/employer's own property. In the context of employment termination, ordinary care means that the employer should not fire an employee in such a way that the employee's human capital is devalued unless the employer would be willing to experience a loss on the same order of magnitude in order to accomplish whatever objective led to the firing. Thus, in order to determine how to define the duty or ordinary care in the employment 
setting, it is necessary to consider the cost of job loss to the employee and the cost of not firing to the employer.

\section{Job Loss Causes Devaluation of Human Capital}

As a rule, job loss diminishes the value of an employee's human capital. Because it is difficult to put a dollar value on accumulated human capital, the best way to estimate the extent to which it has been damaged is to look at the loss of rents attributable to it-that is, the difference between what a given employee would have earned over the course of her career had her employment not been terminated and her lifetime earnings after losing her job. Of course, any such estimate is somewhat speculative since we cannot know for certain what would have happened to any individual employee had she not lost her job. Nevertheless, economists and other scholars have made various estimates.

Workers who lose their jobs experience what one scholar has described as "large and lasting" losses. ${ }^{198}$ Writing in 1993, economists Louis J. Jacobson, Robert J. LaLonde, and Daniel G. Sullivan estimated, based on a large Pennsylvania study of worker separations, that laid-off "high-tenure workers" 199 who had been earning an average of $\$ 24,196$ suffered lifetime earnings losses of approximately $\$ 70,000$ (discounted to present value), or nearly three times their annual salary, as a result of the job loss. ${ }^{200}$ Jacobson, LaLonde, and Sullivan thus compare job loss to "losing an $\$ 80,000$ home in a natural disaster such as a hurricane or flood."201 Their study also found that young workers who lost their jobs also experienced large "postdisplacement earnings losses."202 Most of these losses were attributable to lower wages after reemployment, not to the period of

198. Christopher J. Ruhm, The Time Profile of Displacement-Induced Changes in Unemployment and Earnings, in JOB DisPlaCEMENT: CONSEQUENCES AND IMPLICATIONS FOR POLICY 162, 174 (John T. Addison, ed. 1991).

199. The sample consisted of 9,507 "separators" and 13,704 "stayers," most of whom ranged in age from 27 to 47 . See Louis J. JACOBSON, RoBERT J. LALONDE \& DANiEl G. Sullivan, The Costs OF WORKER DISLOCATION 137, 85-87 (1993).

200. See id. at 137,145 . Their estimate is $\$ 80,000$, but approximately $\$ 9,000$ of this is attributable to eamings losses while still employed due to the declining fortunes of the employer before layoffs become necessary. See id.

201. See id. at 169. Perhaps the recent disaster in New Orleans makes it easier to imagine such a loss and its devastating consequences. One scholar, critiquing META's remedies as insufficient to compensate employees for their true losses, describes the case of a fifty-year-old employee with over thirty years' tenure who was fired when he refused to take early retirement. See Sprang, supra note 9, at 906-08. The employee, who earned between $\$ 65,000$ and $\$ 85,000$ per year, estimated the present value of his lifetime loss, even if he were reemployed immediately, to be over $\$ 500,000$ - between six and eight times his annual salary. See id. at 908 . This estimate may be inflated, as it was generated in the midst of litigation, but it accords with the estimated order of magnitude of loss found in the empirical research done by Jacobson, LaLonde, and Sullivan.

202. See JACOBSON, LALONDE \& SUlLIVAN, supra note 199, at 148. 
unemployment immediately after job loss. ${ }^{203}$ Other studies come to similar conclusions, ${ }^{204}$ especially when older or more senior workers lose their jobs. ${ }^{205}$

It is not difficult to see why job loss results in a financial catastrophe. An employee who is terminated and immediately shown the door usually feels the need to secure new employment right away in order to support herself and her family. Often job seekers feel desperate to reacquire an income stream, and turning down a lower-paying job in the hopes that a higher-paying one will turn up soon enough is a gamble many cannot afford to take. ${ }^{206}$ In a poor economy, of course, these considerations and concerns are amplified. ${ }^{207}$ Once an employee takes a lower-paying job, her lifetime earnings most likely will suffer a significant and permanent setback; in a world in which employers often set wages for new hires based on the salary that the employee commanded in her previous position, taking a job at a lower wage than the job one left is a serious setback.

Not only are job losers desperate to find work right away, but they also are viewed with suspicion by potential employers. Losing one's job for any reason carries a stigma. ${ }^{208}$ Even if there have been mass layoffs, perhaps an individual was laid off because he was among the poorest performers. One scholar writes that managers who have lost their jobs often experience intense self-doubt, wondering if they were cut out in the first place for the kind of job that they lost. ${ }^{209}$ The empirical studies about the financial consequences of job loss are based on data collected largely from individuals who have been laid off for financial reasons; an employee who is fired outside the context of mass layoffs is viewed with even more

203. See id. at 144. The vast majority of employees who had lost jobs were reemployed within a year and a half; the study found that, at most, the period of unemployment accounts for $16 \%$ of the total economic loss. See id. at 143-44.

204. See ADAM SEITCHIK \& JEFFREY ZORNITSKY, FROM ONE JOB TO THE NEXT: WORKER AdJuSTMENT IN A CHANGING LABOR MARKET 32 (1989); NiCK KATES, BARRIE S. GREIFF \& DUANE Q. HAGEN, THE PSYChOSOCIAL IMPACT OF JOB LOSS 81 (1990) (citing MARIE Howland, Plant Closings AND WORKER DISPLACEMENT (1988)).

205. See, e.g., Jeanne Prial Gordus, Paul Jarley \& louis A. Ferman, Plant Closings and ECONOMIC DISLOCATION 81, 94 (1981) (citing studies).

206. See generally BARBARA EHRENREICH, NiCKEL AND DIMED: ON (NOT) GETTING BY IN AMERICA 25-27 (2001) (describing the hand-to-mouth existence of low-wage workers, for whom even a short period of unemployment would be intolerable).

207. Jacob Mincer, explaining empirical observations that employees who quit appear to find better wages than employees who are laid off, writes that an employee who searches for new work while still employed will only leave the current job and accept a new job if the new job pays more (or if the employee thinks it is better for other reasons), while the unemployed have a lower "reservation wage" since they are comparing the prospective wage to (at best) unemployment benefits. See 1 MINCER, supra note 160 , at 201 .

208. See Katherine S. Newman, Falling from Grace: The Experience of Downward MOBILITY IN THE AMERICAN MidDLE Class 69 (1988).

209. See id. at 76 . 
suspicion than an employee who has been laid off. Why take a chance in hiring such a person? The losses faced by such employees are probably as great or greater, generating an even more depressed lifetime earnings profile than those found in the studies discussed earlier. ${ }^{210}$

In addition to wage losses due to the difficulty of finding a job while unemployed and to the stigma of being fired, job loss has also been shown to exact psychological and physical health costs. ${ }^{211}$ Good health is part of human capital, ${ }^{212}$ and these physical and mental injuries are also responsible for post-termination earnings losses, ${ }^{213}$ not to mention the possibility of early death or debilitating illness, both of which can result in significant economic harm as well.

Some of the wage losses suffered by job losers can be explained as a loss of firm-specific human capital. Firm-specific human capital refers to skills that are useful only to the employer for which an employee currently works. ${ }^{214}$ Firm-specific human capital might include, for example, familiarity with proprietary software or good working relationships with other employees. Such skills and relationships have no value to another employer and are thus worthless anywhere else. Thus, when a person loses a job, all firm-specific human capital is lost, and one would expect wages to decline. ${ }^{215}$ General human capital, such as college education, management skills, negotiation experience, or general familiarity with computers, is equally useful to any employer. The lease/bailment concept suggests that employers should not be held responsible for loss of firm-specific human capital. The duty of ordinary care is a limited one that recognizes that the relationship may be ended unilaterally by the lessee/bailee/employer; it suggests only that the termination occur in such a way as to minimize the damage to human capital. It is not apparent that there is any way to do that with regard to firm-specific human capital. ${ }^{216}$

210. That said, when a person is laid off for financial reasons in a declining industry, his inability to find new work may be attributable in large part to a lack of available jobs in his geographical area, a problem that may not be significant in the case of an individual fired for non-financial reasons.

211. See, e.g., KATES, GREIFF \& HAGEN, supra note 204, at 38-68.

212. See BECKER, supra note 159 , at $40-41$.

213. It must be noted, however, that many terminated workers might well experience depression, anxiety, and other mental and physical effects regardless of whether or not they have been fired with notice. Not all mental or physical effects can be attributed to a want of reasonable care.

214. See Schwab, supra note 42 , at 24-25.

215. See id. at 25 .

216. The proposal of termination at will upon the giving of reasonable notice might indirectly result in more employees preserving their firm-specific human capital. One reason is that a required notice period could allow management higher-ups to review termination decisions. In some cases-perhaps many-this would result in the employee's being retained and transferred to another position within the company. This position might be even better suited to the employee's skills and might offer greater opportunity for advancement, thus representing a potential gain in the value of his human capital. Employers might also offer employees an opportunity to appeal supervisors' decisions to fire them 
That said, Katherine Stone's work reveals that today's employers increasingly focus on development of general, or at least industry-specific, human capital in their employees. ${ }^{217}$ As the economy changes in the ways Stone describes and a "new psychological contract" takes hold, firmspecific human capital is becoming less important. ${ }^{218}$ In any event, since job loss has the potential to devalue human capital, if employers have a duty of ordinary care, employers should at least be required to try to minimize the economic cost of being fired.

\section{Costs to Employers of a Good Cause Rule}

The previous section demonstrates that job loss devalues employee human capital, but the duty of ordinary care does not require a bailee to be an insurer. Rather, the bailee is required only to treat the bailed property as if it were his own. This means that the law must also take seriously the importance to employers of being able to fire employees without being required to justify those firings by showing good cause. If the cost to employers of keeping on employees they no longer want is too great, the duty of ordinary care would not require them to do so; in this way, the duty of ordinary care differs from a good cause rule under which an employee would have a right to keep his job unless he did something demonstrably wrong or layoffs were economically necessary.

The costs to employers can be put into two broad categories, namely flexibility and production maximization. If employers could only fire employees for incompetence, malfeasance, or demonstrable economic need, employers would lose the ability to adjust their staffing levels based on, for example, a projection of a future decline in the employer's business without fear of liability. This need for flexibility causes employers to hire temporary workers and independent contractors in order to circumvent legal rules that protect employees.

In addition to flexibility, employers fear losing the ability to maximize the productivity of their labor force. If good cause means that an individual can be fired only for incompetence or malfeasance, it is difficult for employers to demand more than minimal performance. The threat of termination acts as a disincentive to employee "shirking." 19 Even if a good cause rule would require courts or arbitrators to defer to employer judgment

during the notice period or might allow them to apply for other open positions at the company. Such results would be beneficial not only to employees, but also to employers and to society.

217. See Stone, Contract, supra note 169 , at 569.

218. See id. at 552.

219. See Epstein, supra note 12, at 964-65. 
in setting the standard of minimal competence, ${ }^{220}$ employers would be unable to fire a minimally competent incumbent employee simply because a better candidate has come along. Every employer-whether a for-profit business or a non-profit service agency-wants to maximize its total productivity; if an extremely talented individual comes along who can produce twice as much as the person currently occupying a position, a good cause rule would not allow the employer to take advantage of the opportunity.

Finally, at some point taking property and association rights seriously means that it is unfair to require an employer to employ forever an employee that the employer simply does not like. ${ }^{221}$ In terms of the duty of ordinary care-treating another's property as if it were one's own-people often throw away valuable property, such as furniture or clothing, when they no longer like it and no longer want it in the house. ${ }^{222}$ It is not inconsistent with the notion of treating the property of another as if it were one's own to say that circumstances arise in which the relief of being rid of something one doesn't like is worth the financial cost of getting rid of it. This argument has some force, especially if the loss can be minimized-in the case of employment, if an employee can be fired in a way that minimizes the loss to the value of her human capital.

\section{Balancing Employee and Employer Interests: Mandatory Pretermination Notice}

The law of bailments balances the lessee/bailee's right to use the bailed property and the ownership right that the lessor/bailor maintains by imposing a duty of ordinary care on the bailee. It is precisely this kind of balancing that is called for in the employment relationship. Such balancing has been largely absent under the absolutist employment-at-will rule and would be absent under a strict good cause regime. In the context of bailment termination, the law of bailment requires reasonable notice, and

220. Deferring to employers' to set the standard for minimal competence in the position removes some ambiguity, but many marginal cases would remain that would require fact-based determinations by courts as to whether the employee has, as claimed by his employer, failed to meet the standard.

221. See generally Power, supra note 19.

222. Another way of thinking about this point is that to "simply not like something" can mean that there is something wrong with the thing, but it is not possible to articulate precisely what it is that is wrong. See generally MalCOLM GladWell, Blink (2005) (arguing that human beings' split-second determinations are often correct). As Andrew Morriss puts it, "under an at-will regime the firm can act on observable but not verifiable evidence, while under a just-cause rule the firm requires verifiable evidence." Morriss, supra note 43, at 1925. The difference between at-will and good cause rules, then, is that at-will allows employers to act on these inarticulable but often correct "gut feelings," whereas good cause does not; good cause sacrifices the employer's right to use her intuition and instinct in order to protect the victims of the inevitable cases in which the employer gets it wrong. 
notice is a sensible way to balance employer and employee needs in the context of employment termination as well.

\section{a. Advance Notice and the Preservation of Human Capital}

Providing advance notice of impending termination can alleviate the losses experienced by terminated employees in the short term, by making it more likely that the terminated employee can avoid a period of unemployment in which she receives no return on her human capital and during which its value probably declines due to loss of skills, ${ }^{223}$ and in the long term, by increasing the likelihood that an employee can secure a comparable position with little or no loss in pay. Congress recognized the value of notice when it passed the Worker Adjustment and Retraining Notification (WARN) Act, which requires that large companies give sixty days' notice before certain plant closings and mass layoffs. ${ }^{224}$

Receiving pretermination notice should help minimize the loss in value to an employee's human capital for two reasons. First, an employee with notice of an upcoming termination can search for a new job without having to overcome the stigma of having been fired. As discussed in the previous section, this stigma probably makes employers skittish about hiring someone who has recently been fired. ${ }^{225}$ Second, an employee who has received advance notice will be able to conduct a more thorough job search, without the feeling of desperation brought on by a sudden loss of income. ${ }^{226}$ The employee will feel less pressure to take the first minimally acceptable job that comes along if he is not forced to do so because of intense pressure to restore an income stream in order to put food on his family's table. ${ }^{227}$

The evidence is quite strong that giving notice makes it more likely that a job loser can avoid unemployment altogether. ${ }^{228}$ Economist Christopher J. Ruhm writes, "Workers are typically unemployed for an

223. The value of an employee's human capital can decline during a long period of unemployment because the employee is not able to keep up with technological change and to develop skills necessary to maintain the value of her human capital. Scholars have found that workers who receive advance notice of impending job losses are more likely to avoid unemployment than those who have not received notice. See John T. Addison \& Pedro Portugal, Advance Notice, in JOB DisPLACEMENT, supra note 198, at $210-11,223$.

224. See Worker Adjustment Retraining and Notification Act, 29 U.S.C. § 2102(2005).

225. See Christopher J. Ruhm, Advance Notice, Job Search, and Postdisplacement Earnigns, $12 \mathrm{~J}$. LAB. ECON. 1, 20 (1994).

226. See John T. Addison \& McKinley L. Blackbum, A Puzzling Aspect of the Effect of Advance Notice on Unemployment, 50 INDUS. \& LAB. REL. REV. 268, 279 (1997).

227. See Ruhm, supra note 225 , at 20 ("[E]arly notification allows predisplacement search, which could raise wages by reducing liquidity constraints and thereby allowing workers to be more selective in their pursuit of jobs.").

228. See Addison \& Blackburn, supra note 226, at 269-70; See generally Lori Gladstein Kletzer, Earnings after Job Displacement: Job Tenure, Industry, and Occupation, in JOB DISPLACEMENT, supra note 198 , at 123 . 
extended period of time following ... permanent layoffs and often are forced to accept large pay cuts in order to obtain new jobs. . . . [A small] percentage (mostly those with advance notice) are able to avoid unemployment altogether.",229 Some studies have found that notice can also shorten the duration of unemployment (for those who are unable to find a job before they are let go), although others have not found this effect. ${ }^{230}$ The reason most often cited by scholars to explain why notice reduces the chance of unemployment following termination is that the notice period gives the employee time to search for and find a new position before the layoff actually happens. ${ }^{231}$

With regard to the question of wage losses, Stephen Nord and Yuan Ting, looking at data from the Census Bureau's 1988 Displaced Workers Survey, found that employees who received written notice at least sixty days before they were let go were unemployed for shorter periods and also suffered lower earnings losses after they found new jobs, as compared to employees who received no notice or who received less than sixty days' notice. $^{232}$ More empirical work is needed to confirm Nord and Ting's findings and also to determine whether and how much human capital value can be preserved if employers give notice of more than sixty days, but their work is consistent with the understanding of human capital as a commodity whose value declines unless it is returned to its owner in a particular fashion.

229. Christopher J. Ruhm, supra note 198, at 162 (citations omitted)

230. Compare Jane Friesen, Mandatory Notice and the Jobless Durations of Displaced Workers, 50 INDUS. \& LAB. REL. REV. 652, 656 (1997) (finding that notice, up to a point, shortens unemployment duration) with Christopher Ruhm, Advance Notice and Postdisplacement Joblessness, J. LAB. ECON. 1, 26 (1992) (finding that notice can help employees avoid unemployment, but finding no effect on unemployment duration if the employee does become unemployed). Friesen's data come from Canada, which has a mandatory notice system, and thus may be more predictive of the consequences of a mandatory system in the United States; see also Addison \& Blackburn, supra note 226, at 270.

231. See id. at 279.

232. Stephen Nord \& Yuan Ting, The Impact of Advance Notice of Plant Closings on Earnings and the Probability of Unemployment, 44 InDUS. \& LAB. REL. REV. 681, 691 (1991) [hereinafter Nord \& Ting, Plant Closings]. Nord and Ting also found that formal schooling and age appeared to result in lower earnings losses. See id. at 688 . Greater earnings losses were suffered by people with higher pretermination wages, minorities, and women. See id. Nord and Ting write that previous studies that raised questions about whether advance notice helped employees find higher-paying jobs than employees who did not receive notice were based on incomplete data that did not distinguish between notice given by the company and notice that came through the rumor mill. See id. at 683 . Nord and Ting used the 1988 data, which asked about receipt of written notice. See id. A number of economists have questioned whether the data justifies the extent of Nord and Ting's optimism regarding notice. See, e.g., John T. Addison, Douglas A. Fox \& Christopher J. Ruhm, The Impact of Advance Notice: A Comment on a Study by Nord and Ting, 45 INDUS. \& LAB. REL. REV. 665, 672 (1992) (arguing that more research is needed). Nord and Ting have replied to these criticisms by agreeing that more research is needed but underscoring the validity of their preliminary findings. See Stephen Nord \& Yuan Ting, The Impact of Advance Notice: A Rejoinder, 45 INDUS. \& LAB. REL. REV. 674, 681-82 (1992) [hereinafter Nord \& Ting, A Rejoinder]. 
As to the idea being discussed here--that giving pretermination notice can satisfy the duty of ordinary care because it minimizes the loss in value to the terminated employee's human capital-the available data are not sufficient to give a definitive answer for at least two reasons, both of which suggest, however, that notice would be even more effective for fired employees than even Nord and Ting suppose. First, the data available to researchers includes mostly employees who have been laid off for economic reasons, ${ }^{233}$ not those who have been fired for non-economic reasons; there may be important differences between these two groups, especially the fact that employees who are laid off for economic reasons are likely trained for jobs in declining industries, and there may be few (if any) similar jobs available in the geographic area. It may well be much easier for employees who lose their jobs as individuals, in healthy industries, to find new jobs because more potential jobs are available, as long as these employees are given enough time to search and are not stigmatized as having been fired. The effect of notice on employees fired for individualized reasons has not been studied empirically, probably because there is insufficient data and because it is difficult to compare employees fired for a variety of idiosyncratic reasons. ${ }^{234}$ Second, since it is rare for an employer to give more than the sixty days' notice that the WARN Act requires, and most terminated employees get far less notice because their terminations are not covered by WARN, economists do not have much data on the effect of more than sixty days' notice. If somewhat more than sixty days' notice is generally required to find comparable work, currently available data could not demonstrate that fact. ${ }^{235}$

The evidence that employees who receive advance notice of impending termination are able to find higher-paying jobs than employees who do not receive notice suggests that at least some of the post-termination wage loss is attributable to the difference between searching for a new job while still

233. See Nord \& Ting, Plant Closings, supra note 232, at 683 (stating that job loss occurred due to "plant closings, layoffs for which [the workers] had not been recalled, seasonal factors, self-operated business failures, or other reasons"). A later study by Christopher Ruhm also found that employees who received more than sixty days' notice earned more in their next job than those who had not received this notice, but Ruhm is unsure if the notice alone is responsible. See Ruhm, supra note 225, at 23-24.

234. One reason that the proposals advanced in Part IV might benefit from state-by-state experimentation is that different states might adopt different notice periods. The effects of notice in these different systems could be studied, generating definitive answers to the questions of whether notice is effective, how much notice is needed, and when diminishing returns from additional notice are outweighed by the cost to employers.

235. Nord and Ting found that notice of less than sixty days did not reduce wage losses. See Nord \& Ting, Plant Closings, supra note 232, at 688 . If empirical research revealed that advance notice did not help most fired employees retain the value of their human capital-or if this value could only be maintained with a notice period far in excess of what is politically possible to require-then an advance notice requirement would not be justified based on the analysis in this Article. For this reason, among others, it would probably be better for individual states to experiment with various notice periods before a model act were proposed or before the federal Congress should adopt a national advance notice law. 
employed and searching while unemployed. ${ }^{236}$ Notice prevents at least some loss of human capital value by allowing the employee to avoid the stigma of having been fired or laid off, especially if employers are forbidden from revealing to reference-checkers that employees have received pretermination notice. It preserves his reputation, at least until he is actually fired at the end of the notice period. And it prevents the "spoilage" of an employee's human capital that results when he is forced to quickly find a job in order to reacquire an income stream or when he loses skills and a reputation for having skills due to being unemployed for too long. ${ }^{237}$

Even if notice is generally effective at preserving the value of an employee's human capital, this will not always be the case. The same is true in declining industries. And inevitably, some part of a given employee's human capital is firm-specific - of use only to the current employer-and thus likely to be lost upon the termination of that relationship regardless of notice. Nothing short of a good cause rule that would prevent termination altogether can protect employees from the loss of some human capital value due to job termination.

\section{b. Advance Notice and Employer Flexibility}

Depending on the amount of pretermination notice required, a mandatory notice rule would not unduly inhibit employer flexibility. No less an authority than Richard Epstein, the leading defender of employment at will, has written approvingly of pretermination notice. Pretermination notice or severance pay "provide the worker with some protection against casual or hasty discharges, but they do not interfere with the powerful efficiency characteristics of the contract at will." 238 Notice or severance pay

236. See Addison \& Portugal, supra note 223, at 227.

237. One downside of giving notice for employers is that they face the likelihood that they will lose an employee's labor earlier than they would have otherwise (because the employee will find a new job and quit). See Addison \& Portugal, supra note 223, at 211. Addison and Portugal, writing about the WARN Act's mandated sixty day notice period, suggest more research to confirm their sense that mandatory notice is more beneficial to employees than it is costly to employers. See id. at 238-39.

238. Epstein, supra note 12, at 967. Epstein explains his position in further detail:

First, lump-sum transfers do not require the introduction of any "for cause" requirement, which could be the source of expensive litigation. Second, because the sums are definite, they can be easily computed, so that administrative costs are minimized. Third, because the payments are unconditional, they do not create perverse incentives for the employee or heavy monitoring costs for the employer: the terminated employee will not be tempted to avoid gainful employment in order to run up his damages for wrongful discharge; the employer, for his part, will not have to monitor the post-termination behavior of the employee in order to guard against that very risk.

Id. Epstein does not endorse a mandatory notice rule; his discussion of notice and severance pay is in the context of showing that employers and employees can contract around the employment-at-will rule in a variety of ways. But Epstein's points about how notice or severance pay requirements do not "sacrifice[e] the advantages," see id., of the at-will rule are equally applicable to a mandatory notice rule. 
requirements "can be used to give employees added protection against arbitrary discharge without sacrificing the advantages of a clean break between the parties. ${ }^{\prime 239}$ Another scholar, commenting on the modern English system, in which employees are entitled to pretermination notice, writes that a notice requirement "soften[s] the blow of discharge for the worker and impos[es] slightly higher costs on the employer, but it does not really impair the hypothesized functioning of the economy."240

Notice does not seriously distort the economics of the employment relationship because employees have little more incentive to shirk under a notice system than under an at-will system. The marginal performer will not be able to keep her job in either regime; although mandatory notice might allow her to find a new job more easily, eventually her shirking will catch up with her because employers will become suspicious if she moves jobs too often. Indeed, employees might have even less incentive to shirk under an at-will-with-notice system than under the current system because employers would feel more confident firing employees under a less haphazard system than the one they face today.

Employers are free under a mandatory notice rule to end their relationships with employees for any reason, albeit with a slight delay. A notice requirement does not turn employment into a special case, different in kind from the various other economic transactions that a business engages in; it merely shifts employment from one category of economic transactions to another. The employer's property right to control access to the workplace is slightly limited but not abridged. And the employer retains the ability to adjust the composition of his workforce as he sees fit.

Epstein wrote in support of notice as a term of employment that employers and employees could negotiate under the at-will rule, and my claim is not that Epstein would support the proposal advanced here; but Epstein's statement about the relatively modest disruption to the economic considerations with which he is concerned in defending the employment-atwill rule demonstrates that advance notice is not in irreconcilable tension with the perspective of the employment-as-commodity-based defense of employment at will and with the interests of employers in running their businesses as they see fit.

\section{F. Mandatory Pretermination Notice as a Solution to the Employment Termination Law Problem}

In sum, a baseline shift from analogizing employment to a purchase and sale of labor to analogizing employment to a lease of human capital leads to a rule shift from pure employment at will to employment at will

239. Id. at 967.

240. Feinman, supra note 6, at 134. 
with mandatory pretermination notice. Pretermination notice is analogous to the reasonable notice required by bailees who want to terminate bailments. The law of bailments views the provision of reasonable notice as the best way to end a bailment consistent with the exercise of ordinary care, and notice is probably the best way to balance employee and employer interests in the termination of the employment relationship. Retaining the employer's right to terminate employees at will, subject to the requirement of giving sufficient pretermination notice to allow the employee to find a new job, is a win for both employers and employees, allowing both to retain what they most value: employers retain flexibility and control of the workplace, and employees retain their earning power.

IV.

\section{A PROPOSAL FOR REFORM}

In this Part, I offer some preliminary ideas about what the law of employment termination might look like if it were based on the conceptualization of the employment relationship that I have outlined-if it were built around the baseline conception of the employment relationship as a lease of human capital. While I believe this Article would be incomplete without some consideration of how the current rules governing employment termination ought to be modified as a result of the theory that I have proposed, my goal is to flesh out a range of possible modifications to current law or to current proposals for reform ${ }^{241}$ that would be consistent with the idea that the employer takes on a duty of ordinary care for his employees' human capital. I do not present here a single comprehensive reform proposal because I think that there are a variety of possible approaches that are consistent with the duty of ordinary care.

Because of the entrenched nature of the employment-at-will rule, and because reform based on the duty of ordinary care is open to a variety of interpretations, I believe that reform is better left to legislatures than to courts. Indeed, the precise meaning of "ordinary care" in the context of the employment relationship will no doubt be the subject of disagreement and will probably be better defined by experiment than by theory. Thus, the ideas presented below are best viewed as the building blocks for statutory reform of employment termination law based on the duty of ordinary care. $^{242}$ Different states will make different choices-how much notice to

241. I should note that other scholars have proposed some of the ideas discussed here. It is not the individual ideas for reform that are necessarily new, but rather the principled basis for adopting these ideas and rejecting others.

242. This discussion focuses on the key definitional questions relating to the duty itself. Other issues are also important-issues such as whether cases should be decided by courts or arbitrators and whether attomey's fees should be available to successful plaintiffs_-but these are policy questions that 
require, whether to exempt small businesses, what sort of damages to award employees who are fired without notice-and as the strengths and weaknesses of various choices are evaluated and studied, perhaps a consensus will emerge over time. At that point, a new proposal for a uniform law of employment termination might be in order.

\section{A. The Basic Rights and Duties}

The pure employment-at-will rule is inconsistent with an employment relationship that is understood as a lease of human capital. Because the value of an employee's human capital is often the employee's most valuable asset and is likely to be severely damaged if the employee is fired, imposing such a loss without good reason and with little possibility of loss avoidance is at odds with the idea of ordinary care, with the duty of the lessee to treat the leased property as if it were his own. At the same time, as discussed earlier, the pure good cause rule is also inconsistent with the human capital lease model. The duty of ordinary care permits a lessee who has not agreed to a fixed term lease to terminate the lease without cause as long as he does so without causing avoidable damage to the leased property.

A rule governing employment termination that fits with the duty of ordinary care would be one that allows the employer to dissolve the relationship unilaterally if he no longer wants it while minimizing the human capital cost imposed on the employee. The best way to maximize employer flexibility while minimizing employee losses is a mandatory notice requirement. A requirement of mandatory notice is common in other Western countries. ${ }^{243}$ The United Kingdom, Canada, Germany, and France, to name a few, all require a certain notice period before an employee can be let go. ${ }^{244}$ The amount of notice that an employer would be required to give before terminating an employee should ideally be sufficient notice for the employee to find an equivalent position but also not so much notice that the financial, personal, or flexibility cost to the employer is excessive.

Mandatory pretermination notice is different from mandatory severance pay. Notice is more than severance pay because an employee who has received pretermination notice is still employed. Like severance

are independent of the substantive limitations on the right to fire, which is the subject of this Article, and I therefore leave them for another day.

243. See Ronald G. Ehrenberg \& George H. Jakubson, Why WARN? The Impact of Recent Plant Closing and Layoff Prenotification Legislation in the United States, in EMPLOYMENT SECURITY \& LABOR MARKET BEHAVIOR: INTERDISCIPLINARY APPROACHES AND INTERNATIONAL EVIDENCE 202, 202-05 (Christopher F. Buechtmann ed. 1993).

244. See id. It should be noted that these countries generally require notice in addition to good cause protections - that is, employees have a right to keep their jobs unless they give employers good cause to fire them, at which point the employer still must give notice before actually terminating their employment. See id. Here, based on the duty of ordinary care, I propose pretermination notice only, without a good cause requirement. 
pay, notice allows the employee to maintain his income, so he is not in a desperate situation in which he feels forced to take the first plausible job that comes his way. Instead he can-at least for some time-do a more serious search and wait for a position with comparable pay and responsibility, a position that preserves the value of his human capital. But in addition to retaining an income stream, an employee who has received pretermination notice avoids the stigma of having been fired. From the perspective of potential employers, an employee who has been given pretermination notice may simply be looking for a new position because he is ready to move on; in order to ensure that this benefit of notice is effective, states could prohibit prospective employers from asking a job applicant or a current employer whether the employee has received pretermination notice. Since most employers today give no more information to reference checkers than job title and dates of employment, such a restriction would not represent a serious departure from the way employers currently do business.

If an employer is concerned that a disgruntled employee who receives pretermination notice will become destructive, the employer is free to restrict the employee's access to information or property that the employee could steal or destroy so long as the employee is officially maintained on the payroll and in his current position. Such an employee can "telecommute from home" or work in a special office for job seekers that provides no access to sensitive corporate information. While the fear that giving pretermination notice allows soon-to-be-fired employees to wreak havoc in the workplace is often expressed by employers and their advocates, the reality is that many employers voluntarily give pretermination notice, and their workplaces are not destroyed. At least a few American corporations, such as Intel, give very substantial pretermination notice or even help employees find new jobs. While an employer would be free to relieve employees of responsibilities during the notice period, employers who do not fear vindictive behavior could also continue to have notified employees work through the notice period and thus obtain the benefits of their labors, which would be totally lost if the employee were fired on the spot.

\section{B. Exceptions to the Notice Requirement}

Exceptions to the pretermination notice requirement make sense when pretermination notice would not be necessary to constitute employer compliance with the duty of ordinary care. Such would be the case when the loss of human capital value is clearly the fault of the employee or in the case where the employer's economic situation is so bad that the employer has no option other than immediately laying off employees. The duty of ordinary care means that an individual must treat the property of another as 
if it were his own. In typical bailment cases, this means that if a bailee returns the property in damaged condition, a legal presumption arises that the bailee failed to use ordinary care. ${ }^{245}$ This presumption can be rebutted by the bailee by showing that he did use due care. ${ }^{246}$ Thus, an employer should bear the burden of proving that her failure to give pretermination notice was justified.

\section{Malfeasance and Gross Incompetence}

Although the at-will-with-notice rule proposed here is meant to be an alternative to termination only for good cause, when an employee does give good cause for termination, the employer should in certain cases be permitted to fire the employee without notice. ${ }^{247}$ When an employee engages in serious misconduct, any loss to the value of his human capital that results from his being fired is the fault of the employee himself, and the employee cannot claim he is unfairly stigmatized by the firing. An employer who fires an employee, even without notice, whose presence in the workplace is clearly disruptive or destructive has met the duty of ordinary care even if he does not give pretermination notice. The lower wage that the employee is likely to command at his next job, after he was fired for gross incompetence from the last job, is more likely the result of an inaccurate overvaluation of his human capital by the first employer than a loss of human capital value resulting from the firing itself. If the firing is not the cause of the human capital devaluation, the employee has no basis upon which to insist that the employer use a method of firing that will preserve the employee's current wage level. Thus, an employee who gives an employer "good cause" to fire him can be fired without notice.

Treating employee malfeasance or gross incompetence in this fashion under the at-will-with-notice rule is consistent with the warranty implied by the common law that bailed property is "reasonabl[y] fit for the purpose, or capable of the use known to be intended of it,"248 that it possesses "the qualities usually belonging to things of that kind when used for the same purpose."249 This warranty pertains when "the defect is not discernible to the ordinary observer" at the time that the bailment begins. ${ }^{250}$ The destructive or incompetent employee is like a piece of equipment that does not function as advertised. Canadian scholars Terry Wagar and James Grant, reflecting upon Canada's waiver of its notice requirement in cases of

\footnotetext{
245. See, e.g., John T. Handy Co., Inc. v. Carman, 648 A.2d 1115, 1122 (Md. App. 1994).

246. See id.

247. Countries that require pretermination notice generally make exceptions in cases of extremely bad employee behavior. See Hermann \& Sor, supra note 62, at 811.

248. Jones v. Keetch, 200 N.W.2d 227, 229 (Mich. 1972)

249. 8 C.J.S. Bailments $\S 46$ (2006).

250. Id.
} 
poor performance, write that there exists "an implied warranty that the employee is 'reasonably competent' for the work in which he or she is employed."251

Obviously, courts and legislatures will have to struggle with the question of how much good cause justifies immediate termination. Making an exception to the notice requirement in cases of malfeasance or gross incompetence begs the question of how much malfeasance is required or how incompetent an employee must be to be deemed to have breached the "implied warranty of competence." Two considerations are relevant to this question. First, under the ordinary care system, an employee's general entitlement is only to pretermination notice, not to good cause protection. Because the cost of notice is much less than the cost of good cause, an employer should have to show more malfeasance or incompetence to justify firing without notice than the employer would have to show to justify a termination under a good cause system. ${ }^{252}$

The dimensions of good cause for termination have been well developed by labor arbitrators in the unionized setting. ${ }^{253}$ The standards they have developed could be imported to the non-unionized setting. ${ }^{254}$ The employer should, however, be required to show more than good cause in the current labor law sense of that term; the good cause standard found in most collective bargaining agreements must be interpreted to be low enough so as not to require life tenure for poor performers (although some say that this is precisely what does result in a good cause regime), whereas the consequence of not obtaining the malfeasance/incompetence exception to the at-will-with-notice rule is merely having to keep the allegedly poor performer on the payroll for an extra couple of months.

The second consideration can help derive a standard for precisely how much more malfeasance or incompetence must be shown. The principle behind the at-will-with-notice concept is the standard of ordinary care, which means treating the property of the other person as if it were one's own. Thus, to justify a firing without notice, the cost to the employer resulting from the employee's malfeasance or incompetence must be high enough that the employer himself would be willing to suffer a loss of equal-of at least equivalent-magnitude to that which the employee will suffer in order to put an end to the problems being caused by the employee. Because human capital is often an employee's most valuable asset and because being fired devalues it significantly, the employer should be

251. Terry H. Wagar \& James D. Grant, Dismissal for Incompetence: Factors Used by Canadian Courts in Determining Just Cause for Termination, 44 LABOR L. J. 171, 172 (1993).

252. Even under a good cause system, termination is supposed to be a last resort. See Summers, supra note 45 , at 504-05.

253. See id. at 521.

254. See id. 
required to show a correspondingly high cost to keeping the employee around during the mandatory notice period.

To think about how much malfeasance or incompetence justifies termination without notice, it is helpful to think about what an employer would do if a valuable piece of equipment that he owned stopped working properly. For the sake of this discussion, let us assume that an employee is likely to face a lifetime earnings loss of $\$ 70,000$ if he is fired without notice. If the employer owned a piece of equipment that was worth $\$ 70,000$, and the piece of equipment broke, would the employer throw it away or have it repaired? It depends, of course, on how broken the equipment were. If it were irreparably broken or if it were causing severe damage to other equipment, the employer would probably throw it out and absorb the loss. If an employee is "broken" to a comparable extent, the employer should be allowed to terminate her without notice. Otherwise, the duty of ordinary care requires notice.

There is no doubt that under this analysis, it would be difficult to justify termination without notice and that many employers will take the safe route of giving notice in all but the most clearly egregious cases. Employers might find that doing so is cheaper than maintaining the records that would be necessary to prove sufficient malfeasance or incompetence to meet the requirements for the exception to the notice requirement. This can be justified as a sort of employment rule of lenity: it is better to absorb the relatively small cost of giving ten employees unmerited notice than to impose a crushing blow to one employee who does not deserve it.

\section{Economic Emergency}

A second exception to the notice requirement should obtain when an employer is experiencing a severe economic emergency that would make the provision of notice impossible or at least impracticable. The sort of situation contemplated by this exception is when a sudden and unexpected economic downturn requires immediate layoffs just to keep the company afloat. The limits of this exception should also be defined by ordinary care. The question is whether the employer would be prepared to suffer the losses that will be suffered by the laid-off employee in order to stave off the supposedly looming economic disaster. Can the disaster (which must be an extremely severe consequence, although short of bankruptcy) be averted while also giving the employee the generally required pretermination notice? If so, then the economic emergency exception ought not to apply, and the employer must give notice.

Economic emergency should be distinguished from the more typical case of layoffs motivated by economic concerns that do not rise to the level of emergency. Treating someone else's property as if it were your own means allowing that property to come to harm only when there is no 
realistic way to save it. In the typical economically-motivated layoff situation, the employer should be required to give notice.

In thinking about what degree of economic emergency justifies layoffs without notice, the touchstone is ordinary care. An economic emergency should be recognized when the employer's financial situation is so bad that he would be willing to sell off equipment at a loss of the same order of magnitude that the fired employee will suffer. Imagine that an employer owned a piece of equipment worth $\$ 150,000$. Is the employer's financial situation bad enough that he would be willing to sell that piece of equipment right now for $\$ 80,000$ - that is, at a $\$ 70,000$ loss - rather than taking some time to try to find someone willing to buy it at a higher price? If so, then the employer's situation is the kind of economic emergency that would justify firing the employee without notice and remain consistent with the duty of ordinary care.

The WARN Act includes similar considerations. Since WARN applies only to ostensibly economically-motivated mass layoffs and plant closings, Congress clearly agreed that employers, even those in financial distress, can generally be expected to give notice to employees who are about to lose their jobs because of the economic downturn that has hurt the employer. Congress did include in WARN an exception for employers when giving sixty days' notice would be disastrous for the company (although employers are still supposed to give as much notice as they can). ${ }^{255}$ WARN's exception accords with the concept of ordinary care, which recognizes that an employer's financial straits might become so dire that the employer would be willing to suffer some very large losses just to stay afloat.

\section{How Much Notice?}

It is one thing to accept the idea that a mandatory notice requirement fits with the theoretical principle that the employer owes the employee a duty of ordinary care with regard to the employee's human capital. But how much notice should be required?

The determination of the appropriate notice period should take into account the amount of time needed by a typical employee to secure an equivalent position, but it must be balanced against the employer's right to terminate a relationship it no longer desires, the employer's need for flexibility to adjust staffing levels based on business needs, and the employer's need to find a new person to fill the position without paying two salaries for an unreasonably long period.

The competing concerns will be different for different employees and employers. A relatively young employee with in-demand skills, such as 
computer programming, in a good job market may not need much time at all to find a new position and would therefore need very little notice, while an older employee who has built up human capital through experience managing a retail store may have a very hard time finding a comparable position and will need a great deal of notice to make it possible to find a new job before becoming unemployed. A small business may find it difficult to give a great deal of notice because of the economic hardship involved and because of the difficulty of continuing to function with damaged human relationships. A large corporation, on the other hand, may with relative ease be able to absorb the economic effect of long notice periods and can take steps to isolate or transfer an employee who is unable to continue working effectively with his current colleagues.

In giving substance to the reasonable notice requirement, state legislatures and courts might balance these concerns in a variety of ways. There are three basic methods that could be used to determine the appropriate notice period.

\section{Individualized Assessment}

The first possibility is to determine the appropriate amount of notice based on an individualized assessment of the amount of human capital value that a given employee is likely to lose if he is fired. The required amount of pretermination notice would increase if the employee is likely to find it more difficult to obtain comparable work. Factors such as age and seniority have been found to correlate with lifetime post-termination earnings losses, ${ }^{256}$ and these factors could be used by courts to estimate the amount of notice that should have been given to a particular employee.

The courts of some Canadian provinces ${ }^{257}$ engage in fact-intensive, individualized determinations of the "reasonable notice" required by statute. The amount of notice required by statute differs slightly in the various provinces, ranging from one week to a few weeks, and depends on the employee's length of service to the employer. ${ }^{258}$ But Canadian courts have held that the notice required by statute represents only the minimum that must be given, and they often find that much longer notice periods are required. ${ }^{259}$ In determining reasonable notice, Canadian courts look to a variety of factors; the most important appear to be "length of service, salary,

256. See GORdUS, JARLEY \& FERMAN, supra note 205, at 94 (citing James L. Stern, Consequences of Plant Closure, 7 J. Human Res. 3, 3-21(1972)). But see Nord \& Ting, Plant Closings, supra note 232, at 688 (finding that "older workers are more likely to experience smaller reemployment earnings losses than younger workers").

257. See Terry H. Wagar \& Kathy A. Jourdain, The Determination of Reasonable Notice in Canadian Wrongful Dismissal Cases, 43 LABOR L.J. 58, 60 (1992).

258. See id. at 59.

259. See id. 
employee job status, [and] labor market conditions."260 Research indicates that the notice period typically deemed minimally reasonable for "high status" employees is substantially longer than it is for lower status employees. ${ }^{261}$ A study of all Canadian wrongful discharge cases between 1985 and 1990 found that the average length of notice required by courts was nearly nine months. ${ }^{262}$ A range of twelve to eighteen months is common for "senior employees in high status occupations."263

If an at-will-with-notice system uses an individualized inquiry approach, the required amount of notice should be determined not only on the basis of the employee's situation, but also on that of the employer. An employer in financial distress that has not yet reached the status of economic emergency should be required to give some notice to employees it is about to lay off, but ordinary care would mean that such an employer might not be required to give as much notice as would be required if its financial health were not in question.

The advantage of adopting an individualized approach in an at-willwith-notice system in the United States is that the amount of notice required would be no more and no less than necessary to allow the employee affected to find a new position, balanced against the particular financial situation of the employer. Such an individualized approach best reflects the theoretical justification for the at-will-with-notice system.

The individualized approach also has disadvantages, however. The Canadian system, individualized and based on multiple factors, makes it nearly impossible for an employer to determine ex ante how much notice it is supposed to give before terminating an individual's employment. The expected result of such a system would be that risk-averse employers would frequently give more notice than the law requires. Perhaps an individualized approach based on the duty of ordinary care would avoid extremely long notice periods because it would, in determining the meaning of "ordinary care," require analysis not only of the loss suffered by the employee, but also of what is fair and feasible for the employer. Nevertheless, employers would still find it impossible to know in advance how much notice a court might require and would likely err on the side of giving more notice than the standard of ordinary care would deem fair. And even if the amount of required notice could be determined in advance, it would be expensive to do so, necessitating good record keeping by Human

260. See id. at 60 .

261. See id. at 59. These scholars also express concern that Canadian law does not offer sufficient protection to "employees in lower-status occupations." Id. at 62.

262. See id. at 60-61. It should be noted that these findings of what reasonable notice would have been occur after the fact and amount to damage awards. Canadian courts have not supplied a clear formula so that employers can know for certain that they are providing sufficient notice when they terminate an employee.

263. Id. at 59 . 
Resources professionals and supervisors, as well as the involvement of lawyers in every firing.

The real-world difficulty of applying an individualized approach likely outweighs its appeal as the best mirror of the theory behind the ordinary care standard.

\section{Fixed Notice Period}

The second potential approach to the notice requirement is to legislate a fixed notice period, such as thirty, sixty, or ninety days, for all terminated employees. The WARN Act takes this approach. WARN applies only to employees who lose their jobs in mass layoffs and plant closings. ${ }^{264}$ It requires that these employees be given sixty days' notice, a fixed amount that does not vary based on the individual circumstances of the employee or the employer (except for the possible exemption or reduction in the case of an employer suffering an economic emergency).

The appeal of a fixed notice period is predictability. There is no ambiguity under WARN as to how much notice an employer needs to give or how much notice an employee is entitled to receive. If the employer is covered by WARN, the requisite notice period is sixty days. To be sure, some employers will argue that whatever fixed period is required is too much, yet a thirty, sixty, or even ninety day notice period is far less than the extraordinarily long notice periods often required in Canada. The predictability of a fixed notice period means that employers can more easily avoid the prospect of litigation by giving pretermination notice. A fixed notice period should also reduce the concern that employers will be afraid to hire new employees; employers could take hiring risks because the cost of error would be modest and capped at a level known in advance. ${ }^{265}$

The disadvantage of a fixed notice system is, of course, that it is not sensitive to either the particular situations of employers or of employees. Sixty days, for example, is likely to be unfair to one party or the other (or both) in just about every situation. For some employees, sixty days is far more than necessary to find a new job, and for others, it is far less. For employers in dire financial straits, sixty days may represent a significant and unfair hardship; others could easily absorb twice that. The fixed notice period is thus a rather poor implementation of the ordinary care standard's theoretical rationale. Also, in light of Nord and Ting's study, it appears that sixty days is the minimum notice necessary to avoid unemployment and

264. See 29 U.S.C. $\S 2101$ (a) (2000).

265. Perhaps some kind of insurance product could even be developed that would cover the cost to employers of the notice period. Because the cost of notice would be known in advance, the premiums would be relatively straightforward to calculate. 
find a comparable position ${ }^{266}$; if a fixed period of less than sixty days is selected, it would probably do little good for anyone.

\section{The Sliding Scale}

A third approach to determining the required amount of notice is a sliding scale under which employees would be entitled to one of a number of fixed notice periods-for example, fifteen, thirty, sixty, ninety, or one hundred twenty days-depending on whether the employee meets statutorily established criteria, such as age and years of service, that correlate with likely post-termination human capital value loss and with longer search periods being needed to find comparable work. Older or more senior employees would likely need and be entitled to receive more notice than younger or less senior employees, but the amount of notice to which a given employee were entitled could be determined by consulting a simple table. A fifty-year-old manager with twenty-five years of service to the company might be entitled to 120 days' notice, while a thirty-year-old cashier with two years of service might be entitled only to fifteen or thirty days' notice. This kind of sliding scale approach is quite common in European countries that require pretermination notice. ${ }^{267}$

The sliding scale represents a more realistic approach than individualized inquiry, and it fits rather better with the ordinary care standard than a single WARN-like one-size-fits-all approach. The sliding scale captures the predictability of a fixed notice period but is less likely to give an employee significantly more or less notice than necessary to preserve the value of her human capital.

On the downside, this approach introduces line-drawing that is inevitably arbitrary at the margins. ${ }^{268}$ It is also difficult to imagine how the sliding scale approach could account for differences in employer financial conditions, which is an important factor in the standard of ordinary care. Finally, it is not clear that giving less notice to younger or less senior employees makes sense in terms of the effects on human capital value; younger employees might not need as much time to find a new position with only a slight loss in wages, but because a younger worker has so many years of working left, her lifetime wage loss might be the same as that of an

266. See Nord \& Ting, A Rejoinder, supra note 232, at 691.

267. See Ehrenberg \& Jakubson, supra note 243, at 203-05.

268. Also, if the notice period is determined largely on the basis of workplace seniority, as is the case in most countries that use sliding scales, see $i d$., this approach penalizes an individual who has chosen to progress in his career by going to a new employer every few years, as opposed to staying with the same employer for a very long period. While a shorter notice period could be justified by hypothesizing that such employees will be able to find new jobs more easily (either because they are more experienced at job searches or less likely to be stigmatized by job loss), involuntary job loss may be problematic for them as well. One way to approach the problem might be to base the notice period on seniority in the general workforce. 
older employee whose job search takes a bit longer or who has to take a larger pay cut. States that take a sliding scale approach should commission empirical studies to aid in the determination of the factors that best correlate with likely post-termination difficulties in securing comparable employment and the overall lifetime loss of human capital that is likely to result.

\section{Small Employers}

Regardless of which of these three approaches is taken, the problem of fairness to the employer-in particular, the small employer-must be addressed. Since the requirement of reasonable notice is based on the duty of ordinary care, determining the length of the notice period depends on what it means for an employer to take care of an employee's bailed human capital as if it were the employer's own. The notice period must be bounded not only by the employee's need for time to search for a new job, but also by the employer's need to move forward.

Small employers may be less able than large employers to give long notice periods. ${ }^{26}$ For one thing, the economic hardship on a small employer is greater. Continuing to pay the salary of an employee who may no longer be motivated to sustain her former level of productivity, while also searching for and perhaps beginning to pay a replacement, may not be sustainable for long without serious economic hardship. Small employers are also less likely to be able to afford much pre-employment screening, background checking, or testing, with the result that small employers may well end up with a larger proportion of bad hires than large employers. Not only is the expense of the same amount of notice a heavier burden on small employers, but they may find themselves in the position of having to fire people more often. Finally, a large employer may be able to transfer to another department an employee who, for example, is not getting along with his co-workers; this is not an option for most small employers. Thus, "ordinary care" may be different for small employers than for large employers. ${ }^{270}$ States that accept these arguments have a number of options.

First, courts could assess the financial condition of a small business on an individualized basis, reducing the notice period it is required to give according to the court's findings on the likely financial hardship that the otherwise appropriate notice period would pose. Although this approach

269. See Brake, supra note 86 , at 230 .

270. On the other side of the coin, it might be argued that the employer's duty to care for the employee's human capital is the same no matter the wealth of the employer. In the same way that one should not lease equipment if one will be unable to compensate the owner of the equipment if the equipment is broken, one should not hire an employee if one cannot afford to fire him without serious harm. Society's interest in the economic viability of small business, however, probably outweighs insistence on this purist approach. 
might work in a Canadian-style system in which the notice period is determined in the first instance by an individualized assessment of the employee's situation, it would defeat the predictability rationale behind the fixed period and sliding scale approaches. It would also be time-consuming for the courts.

A second possibility is that small employers could simply be exempted from the notice requirement. Many federal employment laws exempt small businesses (although many states merely apply the same rules to small employers through state statutes). The federal WARN Act applies only to large employers. ${ }^{271}$ European countries also often exempt small employers. ${ }^{272}$ While an exemption for small employers has the advantage of protecting small business, it would leave the human capital of the employees of small businesses-much of the U.S. workforce-without any protection at all.

Third, the otherwise required notice period could be discounted based on the size of the employer. In a fixed notice regime, where the required notice period was generally sixty days, for example, only 45 days' notice might be required from employers with 500 - 999 employees, thirty days from employers with 100 - 499 employees, and fifteen days from employers with fewer than 100 employees. ${ }^{273}$ One could also imagine a double-sliding-scale system in which the notice period is determined on the basis of both employee seniority and employer size. Either way, a sliding scale approach would ensure that most employees receive at least some protection, while also recognizing-in accord with the idea of ordinary care-that not every employer is equally able to absorb the costs of extended notice periods.

A fourth option is not to make any exception for small businesses. Clyde Summers wrote that "[t]here is no reason in principle to deny employees protection because they have few fellow workers; indeed, there is some indication that the need for protection may be greatest in small establishments."274 Here, however, there is a principled reason, namely the greater harm to the employer from restrictions on flexibility, which might lead to a different sense of what ordinary care means in that situation.

271. See 29 U.S.C. $\$ 2101$ (a)(1).

272. See Ehrenberg \& Jakubson, supra note 243, at 202-03.

273. It is important to note that the number of employees may not be the best measure of the employer's capacity to give a long period of pre-termination notice. Some employers of relatively few employees-for example, a small hedge fund-may be able easily to absorb a few months' pay. Counting the number of employees, however, is a relatively simple and commonly used method of determining the financial capacity of an employer.

274. Summers, supra note 45 , at 525 (citation omitted). 


\section{Room for Experimentation}

The three employee-based and three employer-based approaches to calculating the reasonable notice period yield nine possible approaches. Assuming that individualized determination is impractical and inadvisable, four approaches remain: (1) a standard fixed notice period with an exemption for small businesses; (2) a standard fixed notice period with a sliding scale discount based on the employer's size; (3) a sliding scale notice period based on employee seniority (or other factors) with an exemption for small businesses; and (4) a sliding scale notice period based on employee seniority combined with a sliding scale discount based on employer size.

Because available empirical data is inconclusive as to precisely how much notice is necessary for fired employees to find a comparable new job without becoming unemployed, and because-employer protests aside-it is not clear how much notice employers could comfortably give, states could experiment with the various approaches described here and with various notice periods to determine the most effective combination. ${ }^{275}$ It may be that such experimentation would yield a single approach that works best everywhere, in which case the Uniform Law Commissioners could step in and propose a uniform law. Or different approaches would work best in different states, perhaps because of geographical and mobility differences, different economic and industrial conditions, or cultural variation. In any event, I do not propose a federal statute or a uniform state law at this point because there is a great deal of empirical data that must be generated in order to determine how best to operationalize the duty of ordinary care in the workplace.

\section{Consequences of Unjustified Failure to Give Notice}

If an employer is under an obligation to give pretermination notice and does not do so, the fired employee should be entitled to a remedy. The remedy should serve two primary functions: it should be sufficient to deter employers from firing without notice and to compensate the employee for the loss of human capital value that results from the wrongful termination. Equitable relief in the form of reinstatement would not be a good idea for two primary reasons. First, reinstatement in the non-unionized setting is rarely successful for long; reinstated non-union employees usually leave within a year. ${ }^{276}$ Second, without a more significant penalty, employers

275. Cf. St. Antoine, supra note 63, at 71 ("State legislation . . offers the . . advantage of an opportunity for some healthy experimentation with alternative procedures.").

276. See Sprang, supra note 9, at 920 . That said, to the extent that they are able to search for a new job from a position of employment, reinstatement would serve to reduce human capital devaluation. 
would have little incentive not to roll the dice and fire an employee without notice; if worse came to worst, the employee would be reinstated.

Remedies available under the WARN Act to employees who are laid off without notice are also insufficient. WARN grants such employees only the wages they would have received had they been given notice. ${ }^{277}$ These remedies do not compensate the employee for the effects of the stigma of having been fired or laid off, and they do not compensate the employeeyears later, at the conclusion of a lawsuit-for the fact that her desperation forced her to take a lower-paying position. WARN's damages are not calculated to address the loss of human capital value caused by firing without notice. Also, the deterrence value of WARN's remedies is limited to the cost of the lawsuit, attorneys' fees, ${ }^{278}$ and a modest fine, ${ }^{279}$ so an employer may well choose to risk not giving notice in order to save the certain cost of giving notice. ${ }^{280}$

Employees fired without notice should be entitled to receive an award that compensates them for the lifetime loss of human capital value that they are likely to suffer because of the firing. Such an award is very much like the remedy of "front pay" that courts on occasion award to the victims of employment discrimination. Front pay is defined as compensation for "future economic losses likely to be suffered between the date of judgment and the time the victim reaches his or her rightful place,"281 which is the same thing as compensating an individual for lost human capital value. Importing the concept of front pay and the mechanisms that courts have used to calculate front pay awards in the context of employment discrimination would accomplish the compensation goal.

An award of front pay in the case of relatively high wage employees who are likely to suffer substantial lifetime earnings losses as a result of being fired without notice will probably be high enough to persuade most employers that it would be cheaper to provide the required pretermination notice of a few months at the most. In the case of relatively unskilled lowwage workers who will have a hard time proving that unjustified noticeless firings will result in large losses to the value of their human capital, a small

277. See 29 U.S.C. $\$ 2104($ a)(1) (2005).

278. See 29 U.S.C. $\$ 2104(a)(6)(2005)$.

279. See 29 U.S.C. $\$ 2104(\mathrm{a})(3)$ (2005). The civil penalties assessed can be up to $\$ 500$ per day of the violation. See $i d$. The maximum penalty would thus be $\$ 30,000$.

280. See Tonya M. Cross, Failure to WARN: A Proposal that the WARN Act Provide a Compensatory, Make-Whole Remedy for UnWARNed Employees, 40 SAN DIEGO L. REV. 711, 723 (2003); Christopher P. Yost, Note, The Worker Adjustment and Retraining Notification Act of 1988: Advance Notice Required?, 38 CATHOLIC U. L. REV. 675, 702 (1988-1989) (citing Joseph Singer, The Reliance Interest in Property, 40 STAN. L. REV. 614, 735 n.388 (1988)).

281. See Valerie Harris, Front Pay and Sexual Harassment Cases: What It Is. Why It Is Important and How to Make It Better, 7 WM. \& MARY J. WOMEN \& L. 217, 228 (2000) (quoting Elizabeth Papacek, Comment, Sexual Harassment and the Struggle for Equal Treatment Under Title VII: Front Pay as an Appropriate Remedy, 24 WM. MITCHELL L. REV. 743, 768 (1998)). 
award may not be sufficient to deter employers from taking their chances by firing without notice. However, assuming that the law also awards attorney's fees to successful plaintiffs, the small award plus attorney's fees might well be more than two months' salary and thus sufficient to have at least some deterrent effect.

To the extent that employers are not deterred, it must be noted that this reform proposal is based on the idea of compensating employees for lost human capital value, measured by lost lifetime wages resulting from being fired in a manner that violates the employer's duty of ordinary care. When an unskilled low-wage worker is fired, assuming that unemployment insurance replaces most of the fired employee's wages and that the employee is able to secure a new job at the same wage level, there may be little to no loss of human capital value. Some may be unsatisfied with the limitations of the ordinary care standard as a basis for employment termination law reform, but this example also demonstrates to pro-employer advocates that ordinary care is a basis for reform that establishes limited employer duties that can shield employers from what they perceive as the excesses of a good cause rule.

\section{E. Statutory and Common Law Exceptions to Employment at Will in an Ordinary Care World}

The adoption of an employment termination rule based on the duty of ordinary care need not be accompanied by legislative elimination of the statutory exceptions to the at-will rule, such as Title VII of the Civil Rights Act of 1964, or of the common law limitations on the rule that are based on contract and tort principles. Because these causes of action, at least in theory, were established to promote societal objectives unrelated to the plight of the individual employee, they should be retained to the extent that those objectives continue to be important.

It should be no more tolerable in our society to fire an AfricanAmerican employee because of her race with notice than it is to do so without notice. And the tort of wrongful discharge as against public policy, for example, functions to prevent employers from using the threat of job loss to force employees to engage in socially undesirable activities. Preserving the tort remains necessary because the threat of being fired, even with notice, may still suffice to bend employees to the wills of their employers.

I believe, however, that if employees had a legal entitlement to pretermination notice, which would ensure that being fired is not a personal disaster for most employees, the courts would feel less need to stretch the statutory and common law doctrines as they have done. ${ }^{282}$ Enacting 
pretermination notice laws would test the hypothesis that the growing use of the common law doctrines results from judges trying to help otherwise unprotected employees. Courts deciding whether to dismiss a wrongful discharge tort claim, for example, would not feel that they had to water down the requirement of a "clearly established" public policy that is at odds with the firing if the fired employee had received enough notice to find a new job. Similarly, a court's willingness to imply contract terms from employee handbooks and other similar sources will likely lessen once employees have other basic protections. But because employers and employees should also remain free to contract for terms more protective than the floor of mandatory pretermination notice, courts should remain free to interpret the terms of employer-employee agreements in the same way that they do for any other contract.

The substantial limitations on the common law actions found in META and the Montana statute are based in part on the fact that employees receive good cause protection under those statutes. If the baseline is good cause, there is arguably little to be gained-other than additional damage awards - by maintaining the viability of the tort of wrongful discharge as against public policy. If an employer cannot prove good cause, which would be the case where the employee has successfully shown that the firing was motivated by a desire to punish the employee for failing to do the socially destructive act that the employer wanted him to do, the employer has acted unlawfully under META and the Montana statute. The at-willwith-notice rule would not make such a firing unlawful, and thus the tort should be retained. Similarly, once employees already have a good cause standard, there is little to be gained by allowing the courts to mine the language of employee manuals for obscure language providing even greater protection of some sort. The costs of such lawsuits very likely outweigh the benefits to employees from the few cases in which additional protections might be found. In an at-will-with-notice world, employees have no protection from termination, and therefore allowing courts to determine whether in fact employers and employees have agreed to job security may well yield results sufficient to outweigh the costs.

\section{F. Contracting Around the Duty of Ordinary Care}

The question whether a new statute governing employment termination should permit employers and employees to contract around the basic rule, agreeing to less protection for employees, is a vexing one. Freedom of contract principles are not threatened by a change in the default rule from at-will to at-will-with-notice or even to good cause; indeed, I have argued that a change to at-will-with-notice is consistent with the rules governing the lease/bailment contracts that are most similar to employment. But freedom of contract principles also require that the parties remain free to 
bargain around the default provisions if they choose to. The reality, however, is that employees will agree to just about anything an employer wants. Whether this is due to employee desperation, inequality of bargaining power, signaling concerns, or lack of information, permitting employers and employees to bargain around the mandatory notice requirement would likely make it worthless. State experimentation on the question whether at-will-with-notice is a default rule or a mandatory rule might be called for to determine whether allowing the parties to contract around the rule undercuts it.

\section{G. A Tale of Two Approaches: Comparison with the Model Employment Termination Act}

Even this preliminary sketch of how the duty of ordinary care could be operationalized in the employment setting reveals an approach quite different from that of the Model Employment Termination Act (META), the most prominent existing proposal for comprehensive reform. While META moves from at-will to good cause, the duty of ordinary care retains the right to fire at will. Because the duty of ordinary care establishes a much more limited entitlement for employees-the right to pretermination notice, rather than the right to life tenure in a particular job-the remedy for a breach of the employer's obligation is greater, and there is no need to eliminate statutory and common law restrictions on the right to fire. While the compromise struck by its drafting committee results in META taking away from employees with one hand what it gives with the other, the duty of ordinary care establishes a principled approach that gives both employees and employers what they most require.

Kenneth Sprang criticizes META for making "wrongful termination suits into an easily valuated cost of doing business,"283 which minimizes the deterrent value of META. The same can be said of the at-will-with-notice proposal. It is important to recognize, however, that the ordinary care proposal does not seek to deter firings. It seeks merely to reduce the harm of firings to employees. Just as important, it seeks to allow employers the flexibility they need to run their businesses. Whereas META's stated aim is to increase job security for employees, this proposal's more limited objective is to minimize (but not eliminate) the loss of human capital associated with employment termination, consistent with the employer's right to end a business relationship within a reasonable period of time. Thus, the very goal of the ordinary care system is that it makes firing employees an easily valuated cost of doing business. Firing employees should cost employers something; it is wrong for employers who wish to end an employment relationship unilaterally to impose enormous costs on

283. Sprang, supra note 9 , at 916 . 
terminated employees without paying a cost themselves. But this cost should be easily valuated so that employers can factor it in as they decide how to adjust to changing business needs and opportunities. As long as the employee's future earning capacity is protected, a system that allows the employer to predict the cost of firing her and act accordingly is a system that serves the needs of both employers and employees. META is an uninspiring and unpopular compromise, but at-will-with-notice represents a third way that has the potential to bring about peace in the workplace and to maximize the ability of both parties to a broken employment relationship to move on without great suffering.

\section{$\mathrm{V}$. \\ CONCLUSION}

Reforming employment termination law by requiring employers to give pretermination notice to their employees in all but a few circumstances would be good for employees and for employers. The benefits to employees are clear and have been described above. Pretermination notice gives the employee a fighting chance of finding a comparable position without an intervening period of unemployment; although being fired is obviously disruptive to an employee's life under any circumstances, at least the financial loss that it imposes can be minimized, which would also minimize the stress, psychological damage, health risks, and other harms that job loss carries with it.

The proposal advanced here-retaining the employment-at-will rule, but also requiring pretermination notice-is pro-employee in the sense that it gives employees more than what they have today. But I believe that regarding the proposal as anti-employer is a mistake. Employers should support the proposal for at least two reasons.

First, although there would be substantial costs to giving notice, there would likely be substantial savings for employers under the at-will-withnotice system. If my hypothesis is correct that courts have been stretching common law contract and tort doctrines because they are uncomfortable with a regime that offers employees no protection at all, a shift to at-willwith-notice would make it less likely that plaintiffs would succeed in these lawsuits. And even if a lawsuit went to the jury, jurors might well be far less sympathetic to the employee who has received sixty days' notice but complains that vague language in an employee handbook entitles him to good cause. Furthermore, it is likely that fewer employees would sue if they were given notice and were able to find new jobs at comparable pay without an intervening period of unemployment. For all these reasons, employers under an at-will-with-notice system would have much less to fear in terms of substantial backpay awards and tort damages; their litigation costs would be reduced, as would various administrative costs 
related to litigation avoidance or minimizing the possibility of losing lawsuits, including employee monitoring, documentation, and pre-hire screening. Because the risk to employers of large damage awards due to termination of a bad hire would be reduced, employers could afford to take more hiring risks than they do today.

Second, although proposals for shifting to a good cause system have not succeeded to date, it remains possible that a deepening sense that the current system is unjust would allow a good cause reform movement to gain traction, at least in some states. It may be to the advantage of employers who oppose good cause to support at-will-with-notice as a way of reducing the public perception that employment termination law is unreasonably favorable to the employer. Most members of the public, after all, are employees.

At-will-with-notice does not suffer from the same problems that proemployer advocates have identified with a good cause system. First, atwill-with-notice is quite simple, especially if the required notice period is fixed or if there is a sliding scale of fixed notice periods. While it may be complex to determine whether there is just cause to fire without notice, these instances are likely to be rare because most employers will opt for the safe route of giving notice. Second, while the cost of at-will-with-notice is higher than pure at will, we do not have a pure at-will system today, and the cost is much less than good cause; if, as discussed above, at-will-withnotice reduces the use of the common law doctrines, it may be cheaper than what we have today.

I do not claim that the lease/bailment concept answers all the criticisms of the employment-at-will rule insofar as those criticisms focus on the human dignity concerns implicated by firings that are not sufficiently justified by poor work performance. Deriving an employer duty of ordinary care over employee human capital by conceptualizing the employment relationship as a lease of human capital formally protects only the economic harm an employee will suffer. The at-will-with-notice system does not directly address the non-economic harm-damage to self-esteem, threat to liberty, loss of identity-to fired employees. At-will-with-notice does not give an employee who is performing well the right to keep her job indefinitely. While I believe that some of the non-economic harms imposed by the employment-at-will rule can be reduced by an at-will-with-notice rule, ${ }^{284}$ the lease/bailment approach is still essentially built around employment as an economic relationship.

284. Non-economic harms might be reduced in a few ways. First, to the extent that the negative psychological and physical costs of job loss are caused by the stress of having to find another job while unemployed and stigmatized, or from being forced to take a lower-paying job that causes an employee and her family to suffer a lowering of living standards, these should be reduced or eliminated under a system that makes it more likely that the employee can find another job without so much stress. Second, 
I also recognize that the lease/bailment conception can be criticized in another way that raises concerns about human dignity. For some, imagining the employee to be leasing his human capital to his employer calls to mind a vision of servitude. The idea of an employee as a freely contracting seller of labor is not complicated by a discomfiting image of one person "possessing" another. This objection can be answered in two ways. First, my argument is not that the employer possesses or controls the employee, but rather that the employer possesses or controls the employee's human capital. Human capital is the productive capacity of a human being, not the human being herself.

Second, and more profoundly, the idea of employment as a lease is an analogy. The claim is not that the employer controls the employee's human capital in precisely the same way that a lessee controls tangible goods. While a lessee, for example, can lawfully exclude a lessor from trespassing upon the lessee's property to repossess the leased goods (even if the actual retention of the goods is unlawful), an employer cannot prevent in any way an employee from walking off the premises. But there are also similarities, and my claim is that the similarities-specifically, that the employer controls the way in which the employee can use her human capital and has the power to damage its value through unilateral action - make the analogy to a lease at least as powerful as the analogy to a purchase and sale.

Our society appears to have-with good reason-concluded that neither the employment-at-will rule, which places unrestricted power in the hands of the employer, nor a good cause rule, which imposes very high costs on employers in an effort to protect employees from being harmed at all, is the proper rule. But we have not been able to agree on what should replace employment at will. At the end of the day, at-will-with-notice is a proposal that balances the objectives and concerns of both parties to the employment relationship in a way that recognizes that the relationship is an economic one whose purpose is to benefit both parties financially, while also recognizing that it is a relationship in which one human being gains the power to inflict serious harm on the other. By retaining the right of a party to an economic relationship to end that relationship without restriction and also minimizing the likely harm to the weaker party from such a termination, an at-will-with-notice rule represents the best available solution to the employment termination law problem.

if employees are able to find a job with comparable pay, prestige, and skill level, perhaps their selfesteem will not suffer greatly; although the fact of being fired still may cause employees to question their worth, finding a new job may put those concerns to rest. Also, employees who are able to secure good new jobs quickly will not have to question their abilities as breadwinners for their families. Third, an at-will-with-notice rule might be more likely to be understood by employees, so being fired will not be the shock to the system that it is for employees - the majority, according to Pauline Kim's studieswho believe they can be fired only for good cause. See Kim, supra note 43, at 110-11. 
